\title{
Keeping the Promise: The ADA and Employment Discrimination on the Basis of Psychiatric Disability
}

\author{
Stephanie Proctor Miller $\dagger$
}

The Americans with Disabilities Act (ADA) and its predecessor, the Rehabilitation Act of 1973, have done a great deal to address the problem of discrimination against individuals with physical disabilities. The ADA has not been as successful, however, in curtailing discrimination based on psychiatric disabilities. In interpreting the $A D A$ in the context of psychiatric disabilities, courts have often turned for guidance to precedents established under the Rehabilitation Act. This Comment argues that much Rehabilitation Act precedent is simply inappropriate for interpreting the ADA, for two reasons. First, the ADA differs from the Rehabilitation Act in ways that should offer greater protection to persons with psychiatric disabilities. Second, many Rehabilitation Act precedents are infused with the very stereotypes and prejudices against individuals with psychiatric disabilities that the ADA ought to avoid. Concentrating on the ADA's employment discrimination provisions, the author examines several of the central questions courts face in cases involving psychiatric disabilities. She suggests ways in which courts interpreting the ADA ought to address these questions, casting aside when necessary the outdated guidance offered by Rehabilitation Act cases.

\section{INTRODUCTION}

The Americans with Disabilities Act $(\mathrm{ADA})^{1}$ has been described as "the most innovative and far-reaching federal civil rights legislation-

Copyright $\odot 1997$ California Law Review, Inc.

$\dagger \quad$ Skadden Fellow, Legal Aid Society of San Francisco, Employment Law Center. B.A., M.S.W., University of California, Berkeley; J.D., Boalt Hall School of Law, University of California, Berkeley. Many thanks to Linda Hamilton Krieger, Arlene Mayerson, Vicki Laden, and Jan Vetter for their helpful comments on previous drafts of this Comment. Also, thanks to Machaela Hoctor, Maria Shanle, and the entire California Law Review for their tireless work and support. Finally, I owe a huge debt of gratitude to my dear friend and husband, Dave Miller, without whom none of my work would be possible. This piece is dedicated to my daughter, Thea, that she may inherit a world with enough justice for us all.

1. 42 U.S.C. $\$ 12101-12213$ (1996). 
ever-on behalf of disabled persons" and "a historic landmark in the civil rights movement." ${ }^{3}$ Congress enacted the ADA to "invoke the sweep of congressional authority, including the power to enforce the fourteenth amendment ... to address the major areas of discrimination faced day-to-day by people with disabilities"4 and to put an end to "the continuing existence of unfair and unnecessary discrimination and prejudice [which] denies people with disabilities the opportunity to compete on an equal basis and to pursue those opportunities for which our free society is justifiably famous." Yet the ADA's promise to end discrimination against people with disabilities in employment, government benefits and services, and public accommodations may go largely unfulfilled for people with psychiatric disabilities. ${ }^{6}$ The use of legal precedent tainted with prejudices against people with psychiatric disabilities perpetuates the very prejudice and false stereotypes that the ADA aimed to dispel.

Somewhere, a man asks for a proinotion to all exciting overseas assignment and is told that his disability would make it unsafe to give him that assignment. ${ }^{7}$ Somewhere, a nurse who struggles to keep her disability under control with a inedication that inakes her sleepy is told that her employer is not required to adjust her work shift. ${ }^{8}$ Somewhere, a worker who is fired the sane day that she is due to return to work from hospitalization and treatment is told that her employer is not required to give her another chance. ${ }^{9}$ Perhaps what these workers were told would have been different if the disabilities that prompted their problems were physical, rather than psychiatric. What would seen to be fairly straightforward issues of reasonable accommodation become muddled soinehow when the disability to be accommodated is a mental illness.

Commentators have suggested that decisions such as these reflect a pervasive bias against the psychiatrically disabled, similar to the irrational prejudices reflected in racism, sexism, and hoinophobia." Bias

2. Michael L. Perlin, The ADA and Persons with Mental Disabilities: Can Sanist Attitudes Be Undone?, 8 J.L. \& HeAlTH 15, 15 (1994).

3. John W. Panty, Mental Disabilities under the ADA: A Difficult Path to Follow, 17 MENTAL \& Physical Disability L. Rep. 100, 100 (1993).

4. 42 U.S.C. $\$ 12101(b)(4)(1996)$.

5. Id. $\$ 12101(\mathrm{a})(9)$.

6. I use the terms mental illness and psychiatric disability interchangeably throughout this Comment, though they do not perfectly map one another. Not all diagnosable mental illnesses rise to the level of being disabling. Questions of what sort of impairments constitute disabilities (and for what purposes) are central to much of the inquiry in this Comment.

7. See Gardner v. Morris, 752 F.2d 1271 (8th Cir. 1985).

8. See Guice-Mills v. Derwinski, 967 F.2d 794 (2d Cir. 1992).

9. See Palmer v. Circuit Court, 905 F. Supp. 499, 506-12 (N.D. Ill. 1995).

10. Perlin terms this type of bias "sanism." Perlin, supra note 2, at 29-31; see also Keri K. Gould, And Equal Participation For All ... The Americans With Disabilities Act in the Courtroom, 8 
against the mentally ill is one of the last invisible and socially acceptable forms of discrimination, perpetuated by our use of uncritically accepted "common sense" and stereotype-based reasoning about mental illness in response to all types of decisions in everyday life. ${ }^{11}$ It is reflected in generally held attitudes toward the mentally ill that are overwhelmingly negative. ${ }^{12}$ Employers' negative attitudes and misperceptions are no different from those of the rest of society..$^{13}$ Neither are those of the judges, lawyers, and legislators who crystallize these prejudices and stereotypes into our legal and political norms. ${ }^{14}$ However, it is these judges, deeply "embedded in the cultural presuppositions that engulf us all,"15 who are charged with interpreting the meaning of the ADA on a case-by-case basis.

J.L. \& Health 123, 137-141 (1994); Michael L. Perlin, On Sanism, 46 SMU L. Rev. 373 (1992) (hereinafter Perlin, Sanism); Michael L. Perlin \& Keri K. Gould, Rashomon and the Criminal Law: Mental Disability and the Federal Sentencing Guidelines, 22 AM. J. CRIM. L. 431 (1995). This bias appears in different forms, including stereotypical assumptions about the worthiness of the mentally ill, paternalistic notions that the mentally ill do not know what is best for them (while a court or an employer does), as well as outright hostility toward and fear of people with psychiatric disabilities. See Perlin, supra note 2 , at $30-40$.

11. See Perlin, supra note 2, at 30 .

12. See Michelle Fine \& Adrienne Asch, Disability Beyond Stigma: Social Interaction, Discrimination, and Activism, 44 J. Soc. Issues 3 (1988); Gary B. Melton \& Ellen G. Garrison, Fear, Prejudice, and Neglect: Discrimination Against Mentally Disabled Persons, 42 AM. PsYChologist 1007 (1987).

13. On the "strongly negative perceptions of workers with psychiatric disabilities," see Laura Mancuso, Reasonable Accommodations for Workers with Psychiatric Disabilities, 14 PSYchosoclaL Rehabilitation J., Oct. 1990, at 3, 4 (citing sources).

14. See Michael L. Perlin, Unpacking the Myths: The Symbolism Mythology of Insanity Defense Jurisprudence, 40 CASE W. Res. L. Rev. 599, $711-31$ (1990). Perlin describes a particularly candid judge offering his opinions on people with mental illnesses:

" 1 had occasion to speak to a state court trial judge about the Rennie case [which granted involuntarily committed patients the right to refuse medication]. He asked me, "Michael, do you know what 1 would have done had you brought Rennie before me?' ...1 replied, 'No,' and he then answered, ' 1 'd've taken the son-of-a-bitch behind the courthouse and had him shot."

Perlin, Sanism, supra note 10, at 401 n.203.

Judicial opinions are replete with examples of prejudice against the mentally ill. The oft-quoted example is Justice Holmes' diatribe in Buck v. Bell, 274 U.S. 200 (1927), against the "menace" of the mentally disabled who should be involuntarily sterilized because "three generations of imbeciles are enough." Id. at 206-07. See also Sinclair v. Wainwright, 814 F.2d 1516, 1522 (11th Cir. 1987) (quoting Shuler v. Wainwright, 491 F.2d 1213, 1223 (5th Cir. 1974)); Com v. Zant, 708 F.2d 549, 569 (11th Cir. 1983) (speaking of a "lunatic"). For instance, judges rarely inform psychiatric patients in involuntary commitment hearings of their rights to counsel or to appeal. See Charles D.H. Parry \& Eric Turkheimer, Length of Hospitalization and Outcome of Commitment and Recommitment Hearings, 43 HosP. \& Community Psychiatry 65, 67 (1992). It is common in some jurisdictions for judges to refuse to render a decision in a commitment or involuntary medication hearing while the mentally ill litigant is in the courtroom. See Gould, supra note 10, at 139. Judges may act on these same stereotypes and prejudices in interpreting broad mandates of the ADA.

15. Anthony D'Amato, Harmful Speech and the Culture of Indeterminacy, 32 WM. \& MARY L. REv. 329, 332 (1991) (quoted in Perlin, Sanism, supra note 10, at 397). 
The major provisions of the ADA have their roots in the Rehabilitation Act of 1973.16 The Rehabilitation Act was the first federal statute to extend civil rights protections to individuals with disabilities, covering individuals employed by federal employers or contractors and individuals receiving federal services. ${ }^{17}$ The ADA expands the scope of the Rehabilitation Act's nondiscrimination mandate to include private employers, requiring that an employer not discriminate against an individual who is otherwise qualified for the job or service on the basis of the individual's disability. The ADA similarly extends the Rehabilitation Act's requirement that covered employers make reasonable accommodations that allow individuals with disabilities to perform a job as long as such accommodations do not impose undue hardships on employers. $^{18}$

However, the ADA also significantly expands the goals and standards of the Rehabilitation Act, with the aim of "[eliminating] discrimination against individuals with disabilities... [and providing] clear, strong, consistent enforceable standards." 19 The fresh start offered by the ADA's passage should cause courts to take a hard look at the case law developed under the Rehabilitation Act in order to rid it of bias against people with psychiatric disabilities. Though the goals and language of the Rehabilitation Act and the $\mathrm{ADA}$ are essentially the same, the passage of the ADA presents an opportunity for courts to meet those goals. $^{20}$ The ADA's statutory and regulatory language and its legislative history indicate a clear repudiation of some courts' interpretations of the Rehabilitation Act. $^{21}$

16. 29 U.S.C. $\$ \S 791,793-94$ (1996).

17. 42 Fed. Reg. 22,675-22,702 (1977) (codified at 45 C.F.R. $\$ \$ 84.1-84.60$ (1996)).

18. See also Barbara A. Lee, Reasonable Accomodation under the Americans with Disabilities Act: The Limitations of Rehabilitation Act Precedent, 14 BeRKeley J. EMP. \& LAB. L. 201 (1993). 42 U.S.C. $\$ 1211$ (9) (1996) provides the following examples of reasonable accomodation:

(a) making existing facilities used by employees readily accessible to and usable by individuals with disabilities; and (b) job restructuring, part-time or modified work schedules, reassignment to a vacant position, acquisition or modification of equipment or devices, appropriate adjustment or modifications of examinations, training materials or policies, the provision of qualified readers or interpreters, and other similar accommodations for individuals with disabilities.

Regulations and technical assistance manuals promulgated by the Equal Employment Opportunity Commission also give examples of reasonable accommodations. See 29 C.F.R. $\$ 1630.9$ (1996);

United States Equal Employment Opportunity Commission Technical assistance Program, Disability Discrimination: Employment Discrimination Prohibited by the AMERICANS WITH Disabilities ACT of 1990 \& $111-5$ (1996 rev.) (hereinafter, Disability DISCRIMINATION).

19. 42 U.S.C. $\$ 12101(b)(1)-(2)$ (1996).

20. The Rehabilitation Act, of course, still remains in effect for federal employers. The logical corollary to the argument in this Comment is that courts should also stop looking to precedent infuscd with prejudice or bias in interpreting the Rehabilitation Act.

21. See Lee, supra note 18 , at 205-08. 
The ADA made important changes in the definition of disability, the meaning of "qualified person with a disability," and the requirement to reasonably accommodate. Under the ADA, disability is determined by whether an individual is substantially limited in a major life activity, without regard to any mitigating measures the person can or does take to alleviate the disability. The $\mathrm{ADA}$ also requires greater scrutiny of the purported qualifications and functions required for a job than was true under the Rehabilitation Act. The determination of whether a person is qualified must be undertaken simultaneously with consideration of what accommodations might allow the person to meet the qualifications. In contrast to the Rehabilitation Act, the ADA clearly requires that employers give due consideration to any reasonable accommodation that will allow people who might otherwise be considered unqualified to perform a job, including reassignment to a comparable position. The ADA sets higher standards than the Rehabilitation Act regarding undue hardship and, consequently, a higher standard for reasonable accommodations. 22

This Comment will focus on the ADA's employment provisions as they affect individuals with psychiatric disabilities. Persons with psychiatric disabilities are especially likely to be unemployed because they experience even greater stigma and exclusion than those with other sorts of disabilities, ${ }^{23}$ even amongst the disabled community. ${ }^{24}$ Employment of people with psychiatric disabilities has been recognized as a key tool to increase their ability to live with dignity and enjoy a decent standard of living. ${ }^{25}$ Employment is also central to decreasing negative public perceptions of the mentally ill. Employers tend to hold especially negative views toward people with psychiatric disabilities. ${ }^{26}$

22. See id. at 206-07.

23. One study ranked attitudes about disabilities from least stigmatized to most, in the following order: ulcers, arthritis, asthma, diabetes, heart disease, amputation, blindness, deafness, stroke, cancer, old age, paraplegia, epilepsy, dwarfism, cerebral palsy, hunchback, tuberculosis, criminal record, mental retardation, alcoholism, mental illness. John L. Tringo, The Hierarchy of Preference Toward Disability Groups, 4 J. SPECIAL Educ. 295 (1970), cited in U.S. Commission ON CiviL Rights, Accommodating the Spectrum of Individual Abilities 26 n.68 (1983).

24. See, e.g., Susan Olson, Clients and Lawyers: Securing the Rights of Disabled PERSONS 47-5I (1984); Perlin, supra note 2, at 20.

25. See, e.g., Perlin, supra note 2, at 34. This Comment focuses on employment with the understanding that it is beyond the capacity of some people with severe and persistent mental illnesses. While employment, and the concomitant increases in self-esteem, self-mastery, and coping skills it can bring, is an option I feel should be considered for all people with mental illness, 1 am sensitive to the criticism that expectations of full employment are unrealistic and possibly damaging. Many people with mental illnesses will continue to need income assistance, but those for whom employment is achievable should be entitled to a work world free of prejudice.

26. See Ira H. Combs \& Clayton P. Omvig, Accommodation Of Disabled People Into Employment: Perceptions Of Employers, 52 J. ReHABILITATION 42, 42-45 (1986); Mancuso, supra note I3, at 4. See also Amerigo Farina \& Robert D. Felner, Employment Interviewer Reactions To Former Mental Patients, 82 J. AbNormal Psychol. 268, 268-72 (1973). 
To be effective in keeping its promise to end discrimination against all people with disabilities, the ADA must be enforced in ways that will combat these employer attitudes. While businesses have begun to comply with the ADA's requirements of accommodation for individuals with physical disabilities, few have developed proactive plans to accommodate individuals with psychiatric disabilities. ${ }^{27}$

This Comment argues that Rehabilitation Act case law that relies on reasoning or statutory interpretation that is inconsistent with the ADA's letter or its nondiscriminatory spirit is not appropriate precedent for interpreting the ADA. Judicial opinions that fail to recognize the differences between the ADA and the Rehabilitation Act-differences of great importance for claimants with psychiatric disabilities-fail to meet the nondiscriminatory promise of the ADA. By the same token, judicial opinions that misunderstand the nature of inental illness, that uncritically apply stereotypical notions about the mentally ill, or that treat those with psychiatric disabilities less favorably than those with physical or no disabilities, cannot be good law under the ADA. ${ }^{28}$ The ADA, a bold new step in acknowledging and in seeking to eliminate the historical prejudices against those with disabilities, must not be infused with those same prejudices in its interpretation. The ADA requires a more sophisticated understanding of inental illness and of the process of accommodating people with mental illnesses in our workplaces-one that makes use of scientific information rather than coinmon assumptions and analytic shortcuts.

Part I of this Comment gives an overview of the employment provisions of the ADA and the Rehabilitation Act. Part II critically examines Rehabilitation Act precedent with particular attention to cases involving claimants with psychiatric disabilities. Though Congress has directed courts to interpret the ADA using Rehabilitation Act precedents, I suggest that for a variety of reasons, courts must cautiously view the persuasive or precedential value of Rehabilitation Act cases, especially those cases dealing with psychiatrically disabled plaintiffs. These reasons include statutory changes and legislative intent, as well as discriminatory bias against psychiatrically disabled people evidenced in the case law,

27. See John F. Fielder, Mental Disabilities and the Americans with Disabilities Act vïi-viii (1994).

28. This Comment focuses on individuals with psychiatric disabilities, rather than on the broader category of mental disabilities. That is, I look chiefly at cases where individuals have disabilities stemming from major mental disorders, such as schizophrenia, bipolar disorder, major depression, and anxiety disorder. Individuals with these disorders tend to experience greater stigmatization and discrimination than individuals with mental disabilities that are mainly developmental, such as mental retardation, or organic, such as stroke or head injury. Major mental illnesses tend to evoke more fear and exclusion, and are more frequently misunderstood by the public at large. Acceptance of people with major mental disorders may pose the greatest challenge to the ADA's nondiscrimination mandate. 
which violates the spirit of the ADA. Part III suggests how to analyze ADA cases brought by individuals with psychiatric disabilities in a way that reflects the spirit of the ADA and embodies a clearer, less stereotyped understanding of mental illness.

\section{I}

\section{The Employment Provisions of the}

\section{REHABILITATION ACT AND THE ADA}

\section{A. The Rehabilitation Act of 1973}

The Rehabilitation Act of $1973^{29}$ granted protection from discrimination in federal employment, federal contracting, and federally-funded programs to people with disabilities. Section $501^{30}$ of the Rehabilitation Act requires federal agencies to establish equal opportunity and affirmative action programs for people with disabilities. Section $503^{31}$ requires federal contractors to make reasonable accommodations for the physical and mental limitations of qualified applicants or employees with disabilities unless those accommodations would impose undue economic hardship. ${ }^{32}$ Section $504^{33}$ of the Act applies these same standards to recipients of federal funds, such as universities.

The basic concepts of the Rehabilitation Act, though fairly straightforward, came about only after much contention and pressure. Though the Act became law in 1973, regulations to implement the Act were delayed for years and then issued only after activists in the disability community sued to force their promulgation. ${ }^{34}$ Section 504 of the Act reads, "No otherwise qualified individual with a disability in the United States... shall, solely by reason of his or her disability, be excluded from the participation in, be denied the benefits of, or be subjected to discrimination under any program or activity receiving federal financial assistance." 35 The Rehabilitation Act defined "individual with disability"36 as "any individual who ... has a physical or mental impairment which for such individual constitutes or results in a substantial impediment to employment." ${ }^{\text {"37 }}$ This would include having a "physical or

29. 29 U.S.C. $\$ \S 706,791,793-794$ (1996).

30. Id. $\$ 791$.

31. Id. $\$ 793$.

32. The terms "reasonable accommodation" and "undue hardship" were not part of the original statutory language but were established in the implementing regulatory language. See 45 C.F.R. $\$$ 84.12 (1996) (Department of Health \& Human Services regulations related to recipients of federal funds); 29 C.F.R. $\$ 1613.704$ (1993) (regulation related to federal agencies).

33. 29 U.S.C. $\$ 794$ (1996).

34. See Cherry v. Mathews, 419 F. Supp. 922 (D.D.C. 1976).

35. 29 U.S.C. $\$ 794$ (1996).

36. The original statute and regulations used the term "handicap." The regulations have since been amended so they use the preferred term "disability."

37. 29 U.S.C. \& 706(8)(A) (1996). 
mental impairment which substantially limits one or more of such person's major life activities," "a record of such an impairment;" or being "regarded as having such an impairment." After this threshold requirement for coverage is met, a person must demonstrate that she is qualified to perform the job. The Rehabilitation Act states that a qualified person is one who with or without reasonable accommodation, can perform the essential functions of the job. ${ }^{39}$ Reasonable accommodations are those that do not impose an undue burden on the employer. ${ }^{40}$ It is these hard-won basic concepts that formed the backbone of the ADA.

\section{B. The Americans with Disabilities Act of 1990}

The Americans with Disabilities Act was patterned directly after the Rehabilitation Act. Much of the ADA's terminology, including "qualified individual with a disability," "reasonable accommodation" and "undue hardship," tracks the language of the Rehabilitation Act." Title I of the ADA, the section dealing with employment, provides that no covered private employer may discriminate against qualified applicants and employees on the basis of disability. ${ }^{42}$ As of July 26, 1994, covered employers include all private employers with fifteen or more employees, and all state and local governments, regardless of size. ${ }^{43} \mathrm{~A}$ qualified individual with a disability is "an individual with a disability who meets the skill, experience, education, and other job-related requirements of a position held or desired, and who, with or without a reasonable accommodation, can perform the essential functions of a job." Employers may not discriminate against qualified individuals with regard to any employment practice or the terms, conditions, or privileges of employment, including application, testing, hiring, promotion, medical examinations, compensation, or benefits. ${ }^{45}$

The ADA requires that the employer make a reasonable accommodation to the known physical or mental limitations of a qualified applicant or employee unless the employer can show that such an accommodation would create an undue hardship..$^{46}$ Reasonable accommodations are changes in the work structure or work environment that

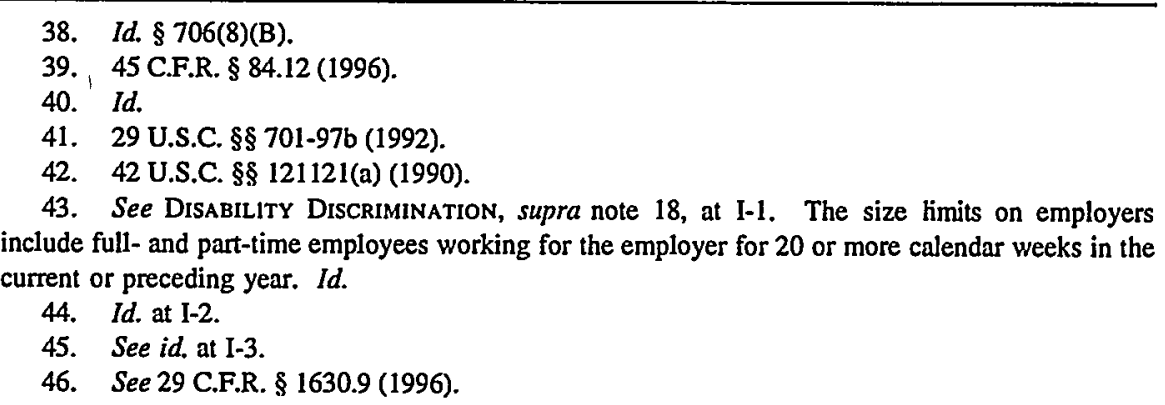


allow an individual with a disability the opportunity to compete equally with those who do not have such limitations. ${ }^{47}$ Examples of reasonable accommodations recommended by the Equal Employment Opportunity Commission's (EEOC) technical assistance program include modifying the physical arrangement of the workplace to increase accessibility, modifying work schedules, reassigning a disabled employee, acquiring assistive devices, equipment or software, and providing readers or interpreters. ${ }^{48}$ Though several of these accommodations could potentially apply to workers with mental illnesses, almost all of the examples of accommodations given by the EEOC apply to people with physical limitations. ${ }^{49}$

The EEOC regulations provide a four-step process for determining what is an effective "reasonable accommodation" when the employer and employee are unable to agree on one..$^{50}$ First, the job is analyzed in terms of its essential functions and requirements. Second, the disabled individual's abilities and limitations are compared to these functions and requirements in order to identify what if any barriers to performance are present and how they might be overcome. Third, in consultation with the individual, the employer identifies potential accommodations and assesses how effective each would be in enabling the individual to perform the job's essential functions and requirements. Finally, taking into consideration the needs of both employee and employer, an accommodation is selected from among those assessed as effective. If no accommodation is found to be effective or acceptable to the employee, the employee is considered not qualified for the position.

An accommodation is not "reasonable" if it imposes an undue hardship on the employer. The ADA broadly defines undue hardship to include any action that is "excessively costly, extensive, substantial, or disruptive, or that would fundamentally alter the nature or operation of the business." 51 The regulations do not specify what constitutes an undue burden; recominendations to cap employers' burdens have thus far been rejected. $^{52}$ Of particular importance in the realm of

47. See id. § 1630.2(0).

48. Disability Discrimination, supra note 18 , at I-5.

49. For the one example in the EEOC's original guidance manual of a reasonable accommodation that specifically mentions mental illness, see $i d$. at $11 \mathrm{l}-20$ (modified work schedule for person in therapy).

50. See id. at 11I-8-9.

51. Id. at I-5.

52. The House Judiciary Committee rejected a proposed amendment that would have fixed a ceiling of $10 \%$ of the employee's salary as the maximum accommodation an employer would be required to provide. The proposal was rejected in part because it would have had a disproportionately severe impact on lower-income workers. H.R. Rep. No. 485-I01, pt. 2, at 41 . (1990). For a criticism of the House's rejection of this amendment and its potential effects on small business, see David Harger, Comment, Drawing the Line Between Reasonable Accommodation and Undue Hardship Under the Americans with Disabilities Act: Reducing the Effects of Ambiguity on 
accommodations to mental illness is the EEOC's statement that disruption due to employees' fears, prejudices, or negative reactions to accommodation of the disabled individual do not constitute an undue hardship. ${ }^{53}$

The ADA recognizes that individuals with psychiatric disabilities need protection from job discrimination to the same degree as those with physical disabilities. Most people with psychiatric disabilities are able to perform their duties in the workplace competently and without causing problems. Many employers mistakenly believe that individuals with psychiatric disabilities are more prone to violent behavior, are likely to disturb co-workers or customers, or will be too difficult to supervise. $^{54}$

Employers also fear that making a claim of psychiatric disability discrimination under the ADA will be too easy and will result in false claims by people trying to keep jobs they cannot perform. ${ }^{55}$ What most employers do not fully grasp is that the ADA definition limits qualifying disabilities to those that "substantially limit[] . . . major life activities." To be protected by the $\mathrm{ADA}$, an individual must have an impairment that meets this definition, must be regarded or perceived as having such an impairment, or must demonstrate a record of having such an impairment. Employers are not required by the ADA to provide reasonable accommodations to individuals whose disability does not fall within the ADA's scope of protection.

Employees with hidden disabilities like psychiatric illness must make their need for an accommodation known to their employer in order to be covered by the ADA..$^{57}$ If an applicant has a known disability or an obvious one that appears to limit, interfere with, or prevent the individual from performing job-related functions, the employer may inquire as to how the applicant or employee would perform the function with or without a reasonable accommodation. ${ }^{58}$ If an individual with a known disability is having difficulty performing the job well, the "employer should assess whether this is due to a disability." If the need for accommodation is not obvious, the einployer may request documentation of the individual's functional

Small Businesses, 41 U. KAN. L. REv. 783 (1993).

53. See Disability Discrimination, supra note 18 , at III-13.

54. See President's Committee on Employment of People with Disabilities, Common Misperceptions About Psychiatric Disabilities (unpublished report, on file with author).

55. See id.

56. 29 C.F.R. \& 1630.2 (g)(1) (1996). Of the first I1,500 EEOC complaints filed under the ADA, $9.8 \%$ were due to mental illness. Some 700 of these were not amenable to resolution by the EEOC, and right-to-sue letters were granted to the complainants. See FiELDER, supra note 27, at viii.

57. See 29 C.F.R. $\$ 1630.9$ (a) (1996).

58. See Disability DisCRIMINATION, supra note 18 , at Ill-7.

59. Id. 
limitations. Not surprisingly, many employees with mental illnesses or histories of mental illness have been reluctant to give employers such information for fear of making themselves vulnerable to discrimination..$^{60}$

Though the basic concepts of the Rehabilitation Act and the ADA are straightforward, the nuances of each prong of a disability claim can make analysis a complicated matter, particularly when the claimed disability is not well understood. This complexity has meant that courts have had to search for guidance to make sense of ADA claims, often relying unquestioningly on Rehabilitation Act precedent.

II

\section{INTERPRETING THE ADA}

Commentators have suggested that Rehabilitation Act precedent is appropriate for interpreting and clarifying the sometimes murky requirements of the ADA. The legislative history in fact directs courts to look to Rehabilitation Act precedent for guidance. ${ }^{61}$ However, in at least a few key areas, where legislators adopted new standards, Rehabilitation Act precedent is clearly inapplicable. ${ }^{62}$ Further, in many decisions involving mentally ill claimants, the standards under the Rehabilitation Act conflict with the spirit of the ADA and are thus inapplicable. Thus, despite the similarities between the two Acts, there are numerous differences between them that require careful examination.

As similar as the two statutes appear facially, there are significant differences between the ADA and the Rehabilitation Act in each element of a discrimination claim. To make out a prima facie case of disability discrimination under the ADA, plaintiffs must plead three elements: (1) that they have a disability, (2) that they are qualified for the job and can perform its essential functions either with or without reasonable accommodations, and (3) that their employer excluded them based on their disability. ${ }^{63}$ The following Sections examine how proving each of these elements differs under the $\mathrm{ADA}$ and the Rehabilitation Act for claimants with psychiatric disabilities. Section A examines the definition of disability and the extent to which individuals with psychiatric disabilities are considered disabled for purposes of the ADA. Section B turns to the question of qualification for a job and some of the limitations on qualification with particular importance for individuals with

60. FIELDER, supra note 27 , at 10-11.

61. See S. Rep. No. 116-101, at 21 (1989); H.R. Rep. No. 485-101, at 27 (1990); H.R. Rep. No. $485-101$, pt. 2, at 50 (1990).

62. See Lee, supra note 18 , at 236.

63. See Jeffrey O. Cooper, Comment, Overcoming Barriers to Employment: The Meaning of Reasonable Accommodation and Undue Hardship in the Americans with Disabilities Act, 139 U. PA. L. REv. 1423, 1463 n. 226 (1991). 
psychiatric disabilities. Section $C$ looks at the concept of reasonable accommodation, the difficulty of applying this concept to the limitations of people with psychiatric disabilities, and the undue burden limitation on accommodations. Each Section contains recommendations for the appropriate way to resolve conflicts between the ADA and the Rehabilitation Act, which are summarized at the conclusion.

\section{A. Definition of Disability}

To be protected by either Act, an individual must first show that his impairment meets the Act's definition of a disability. The ADA prohibits discrimination "on the basis of disability," ${ }^{64}$ while the Rehabilitation Act's original language prohibited discrimination "solely by reason of' her or his disability. ${ }^{65}$ Under the Rehabilitation Act, several courts interpreted that difference in language as requiring plaintiffs pleading disability discrimination to demonstrate that the employee's disability was the "sole cause" of the employer's action. "Under the ADA, however, the employee need only show that disability discrimination was one of the reasons the employer took the allegedly discriminatory action. ${ }^{67}$

The ADA defines disability as "(a) a physical or mental impairment that substantially limits one or more of the major life activities of [the] individual; (b) a record of such an impairment; or (c) being regarded as having such an impairment." ${ }^{\text {"T8 }}$ This is the exact language used in the Rehabilitation Act. The EEOC's regulations implementing the $\mathrm{ADA}$ also use the same language as the regulations under the Rehabilitation Act in defining "mental impairment" as "[a]ny mental or psychological disorder, such as mental retardation, organic brain syndrome, emotional or mental illness, and specific learning disabilities."

The ADA's regulations and Rehabilitation Act precedent addressing what types of impairments will be considered qualifying disabilities raise important questions for people with psychiatric disabilities. If a person with a psychiatric disability can control her symptoms with medication, is she disabled? If a person with a psychiatric disability is

64. 29 C.F.R. \& 1630.4 (1996).

65. See, e.g., Davis v. Frank, 711 F. Supp. 447, 455 (N.D. Ill. 1989)

66. See, e.g., Matzo v. Postmaster Gen., 685 F. Supp. 260, 263 (D.D.C. 1987), aff'd without op., 861 F.2d 1290 (D.C. Cir. 1988); Maryland Comm'n on Human Relations. v. Mayor of Baltimore, 1 Nat'l Disability L. Rep. (LRP) II 256 (Md. Ct. Spec. App. 1991).

67. The Rehabilitation Act has been amended to adopt the same standard as the ADA. See, e.g., Biddle v. Ruben, 6 Nat'l Disability L. Rep. (LRP) I 372 (N.D. III. 1995) (holding that plaintiff did not have to plead disability as "sole cause" after ADA changed the Rehabilitation Act standard).

68. 29 C.F.R. \& 1630.2(g) (1996).

69. 28 C.F.R. \& 41.31(b)(1). Though this Comment focuses on various forms of emotional or mental illnesses, such as bipolar (manic-depressive) illness, schizophrenia, depression, and anxiety disorders, other types of mental impairments raise similar issues. 
unable to perform some required skill, is he disabled or only disqualified from that one particular job? Is a diagnosis with a major mental disorder, that is by definition episodically but substantially impairing, a disability per se? The answers courts gave to these questions under the Rehabilitation Act are no longer applicable to claims raised under the ADA.

\section{Conditions Controlled by Medication}

One of the key questions raised by the definition of disability for people with mental illnesses is whether individuals whose conditions are completely or substantially controlled by medication are nevertheless considered substantially impaired. Under the Rehabilitation Act, the answer appeared to be no. In Mackie v. Runyon, ${ }^{70}$ Mackie, a Postal Service employee, was diagnosed with bipolar disorder. ${ }^{71}$ She was able to keep her symptoms under control with Lithium. ${ }^{72}$ She consistently received excellent performance evaluations for her work on the night shift, but was told by her doctor that the erratic sleep patterns that resulted from working this shift part-time were likely to exacerbate her condition and lead to relapse. ${ }^{73}$ For one year, Mackie submitted requests to have her shift changed to a more regular one, submitting medical reports documenting her need for the change, but her requests were repeatedly denied. ${ }^{74}$ After being denied a final time, Mackie did not return to work and the Postal Service fired her. The court found that, because Mackie's bipolar disorder was controlled by her medication, it did not substantially impair her life functions, and therefore did not qualify as a disability under the Rehabilitation Act. ${ }^{75}$

The court's analysis suffers from a fundamental misunderstanding of mental illness. Bipolar disorder is one of the most severe mental illnesses. ${ }^{76}$ Though many people suffering from the disorder can function well with medication, some claimants have been able to demonstrate that even with the assistance of medication they are still subject to substantial limitations due to the medication's side effects or symptoms that do not

70. 804 F. Supp. 1508 (M.D. Fla. 1992).

71. Bipolar Disorder, commonly known as Manic-Depression, is characterized by extreme mood swings from manic, bordering on delusional, highs and deep, suicidal lows. See AmericaN Psychiatric Ass'n, Diagnostic \& Statistical Manual of Mental Disorders 350-55 (4th ed. 1994) (hereinafter, DSM IV) (defining Bipolar Disorder).

72. See Mackie v. Runyon, 804 F. Supp. 1508, 1509 (M.D. Fl. 1992).

73. See id.

74. See id. at 1509-10.

75. See id. at 1510-11.

76. See Roberta G. Sands, Clinical Social Work Practice in Community Mental HEALTH I83-86 (1991) (including bipolar disorder in a discussion of chronic and severe mental disorders). 
respond to the medication. ${ }^{77}$ The court does not pretend that people who use prosthetics or wheelchairs to give them mobility are no longer disabled with the use of these devices. It is foolish to act as if a person with a mental illness, who may need to take medication indefinitely to prevent relapse, is somehow no longer disabled with the medication in place.

The changes wrought by the ADA call into question the rule established in Mackie. The ADA regulations indicate that the existence of an impairment should be determined without regard to any mitigating measures such as medicine or therapy. ${ }^{78}$ The appendix to the regulations gives the example of an individual with epilepsy, who would be considered to have a disability even if symptoms of the disorder are completely controlled by medicine. ${ }^{79}$ The same logic would apply to Mackie and to others who have mental illnesses. ${ }^{80}$ Therefore, Mackie and other cases that relied on its interpretation of the Rehabilitation Act are inappropriate precedent for interpreting the ADA definition of disability.

Liff $v$. Secretary of Transportation ${ }^{81}$ demonstrates a better approach to the issue of mental illness controlled by medication. In Liff, an attorney's employer removed her from her position and transferred her to another job because she was suffering from depression. The attorney challenged this action as discrimination based on her disability. The defendant employer moved for summary judgment on the grounds that the attorney's depression was not a disability under the Rehabilitation Act because her depressive symptoms were controlled by medication. The court denied the motion because evidence from the plaintiff's physician would support a finding that the plaintiff had a mental impairment that substantially limited one or more major life activities despite the fact that the impairment was mitigated by medication. ${ }^{82}$

The approach used in Liff is particularly important for people with mental illnesses for several reasons. First, employers may base their judgments about the person on his or her diagnosis, regardless of the

77. See, e.g., EEOC v. Union Carbide, 1995 WL 495910, *2 (E.D. La. 1995).

78. See 29 C.F.R. 1630 app. $§ 1630.2(j)$ (1996); see also H.R. Rep. No. 485-101, at 28 (1990); H.R. Rep. No. 458-101, pt 2., at 52 (1990); S. Rep. No. 116-101, at 23 (1989); Disability Discrimination, supra note 18, at $\$ 902.5$ “Mitigating Measures," p. 35.

79. See 56 Fed. Reg. 35,741 (1991).

80. The more recent EEOC Compliance Manual Directive indicates as much. EEOC DiRECTive No. 915.002, at 902-36 (March 14, 1995), reprinted in UNited States Equal EMPLOYMENT OPPORTUNITY COMMISSION, Disabillty DiscriMINATION: EMPLOYMENT Discrimination Prohibited By THe ADA, App. E. (1995). However, the EEOC Manual is not mandatory authority. See, e.g., Schluter v. Industrial Coils, 8 Nat'l Disability L. Rep. (LRP) II 197 (W.D. Wis. 1996).

81. 5 Nat'1 Disability L. Rep. (LRP) I 405 (D.D.C. 1994).

82. See id. 
mitigating effects of medication. Though such judgments are technically covered by the "regarded as" or "record of" prongs of the definition of disability, in reality those latter prongs may be more difficult for employees to prove. Also, people with mental illnesses may experience relapse or "breakthrough" symptoms even with medication. Thus, judges examining cases where employees with mental illnesses control their symptoms with medication should look to the EEOC's guidance and to cases like Liff, rather than Mackie and similar cases decided under the Rehabilitation Act.

Cases such as Franklin v. United States Postal Service ${ }^{83}$ raise a similar, but more difficult, question. Franklin was a postal employee diagnosed with paranoid schizophrenia. Though Franklin was able to control her symptoms when she consistently took her medication, she frequently did not take it, complaining of unpleasant side effects. ${ }^{84}$ When she did not take the medication, her paranoid symptoms would increase, resulting in three occasions, occurring outside of her workplace while she was not working, where she allegedly threatened public officials. ${ }^{85}$ Failure to take her medication also led to extended hospitalizations and absences from work. The court in Franklin sought to distinguish between a "handicap" and a condition the court saw as created by the plaintiff. ${ }^{86}$ "The choice being [Franklin's], it seems difficult if not impossible to understand why the actions of the defendant [in firing her] should be deemed to be discriminatory." ${ }^{87}$

Though the facts of Franklin are extreme-the employee was absent from work 464 days in three and a half years-the holding implies that if an employee with a mental illness fails to take medication, the employer can justifiably terminate her because she is not actually disabled. Insofar as Franklin implies that choosing to go off medication means that a person's impairments are "voluntary," and therefore not true disabilities, it has confused the issue of existence of a disability with qualification for a job. Though Franklin was almost certainly unable to fulfill the essential functions of the job when she chose to go off medication, there is no doubt that she was disabled by her illness.

The court's analysis here, eliminating the plaintiff's claim on the basis that she was not disabled, rather than not qualified, is faulty. Though it makes little difference to Franklin's result, it remains as confusing and harmful precedent for the next claimant with a psychiatric disability. Further, insofar as Franklin implies that employees with

\footnotetext{
83. 687 F. Supp 1214 (S.D. Ohio 1988).

84. See id. at 1217.

85. See id. at 1216.

86. See id. at 1218.

87. Id.
} 
mental illnesses might be required to take medication as a condition of employment, it is inappropriate precedent for interpreting the ADA. The only relevant question for analysis is whether the claimant can perform the essential functions of the job, not whether she is willing to do what the employer thinks is best to control the symptoms of her disability.

\section{Disqualification from One Job or Type of Job}

A claimant can demonstrate that she is disabled by presenting evidence that she is substantially limited in the major life activity of working. ${ }^{88}$ The regulations provide that substantially limited in working means that the claimant is restricted in her ability to perform either a class of jobs or a broad range of jobs; the inability to perform a single, particular job is not a "substantial limitation." ${ }^{\text {" }}$ Rehabilitation Act precedent is also inadequate for addressing issues of psychiatric disability in that it too frequently construes the single job exception very broadly, accepting employer claims that inability to perform some work function only precludes the claimant from performing a single job. The oft-cited example is Forrisi v. Bowen, ${ }^{90}$ in which the Fourth Circuit affirmed a lower court ruling that an employee with acrophobia could not claim protection under the Rehabilitation Act because this impairment did not qualify as a disability. ${ }^{91}$ The employee was working at a job that required him to climb stairs and ladders for periodic maintenance and in emergencies. He informed his manager that he could not climb to certain heights, but that he could do the necessary work if some adjustments were made to accommodate his impairment. ${ }^{92}$ His employer subsequently found him "medically unable to perform" his job and fired him. ${ }^{93}$ Though the employee argued that he was being discriminated against because his employer perceived him as disabled, the employer prevailed with the argument that the employee was not regarded as being disabled but rather simply incapable of performing a particular task at a particular job. ${ }^{94}$ The court found that, "[t]he Rehabilitation Act assures that truly disabled ... individuals will not face discrimination in employment because of stereotypes about the insurmountability of their handicaps. ${ }^{195}$ The court viewed impairments such as Forrisi's as being no different from the average person's fears

\footnotetext{
88. See 29 C.F.R. § 1630.2(1) (1996).

89. See id. \&1630.2(j)(3).

90. 794 F.2d 931 (4th Cir. 1986).

91. See id. at 931 .

92. See id. at 933.

93. Id.

94. See id. at 933-34.

95. Id. at 934 (emphasis added).
} 
and held that treating them as disabilities would "debase" the purpose of the Act. ${ }^{96}$ What the court failed to realize is that Forrisi's illness is, in fact, different from the average person's fears, given that he had a diagnosed mental illness. ${ }^{97}$

The court in Cadelli v. Fort Smith School District ${ }^{98}$ reached a similar result. The court found that the plaintiff's panic disorder was not a "handicap" within the meaning of Section 504 because the disorder only impaired his ability to perform a particular job, teaching "a certain number of a certain kind of class during a particular school year." 99 Plaintiff, a high school teacher, submitted evidence that his disorder impaired his ability to complete a heavy teaching load consisting of six life science classes, but that he felt he would be able to teach in a smaller classroom and that he eventually would be able to return to his customary duties. The court found that because his alleged impairment had not affected earlier assignments or his ability to fill alternate positions, his panic disorder was not a substantial impairment and thus not a disability under the Rehabilitation Act.

Cadelli typifies a gray area of ADA coverage for people with psychiatric disabilities. Cadelli's impairment made him unable to continue his customary work, but he thought he might be able to continue some sort of work for his employer with the accommodation of reassignment. His doctor corroborated his claim of substantial impairment and the need for accommodation. Yet, because Cadelli did not show a higher degree of impairment or allege long-term impairment, his condition was not found to reach the level of a disability under the Rehabilitation Act. The court rejected his claim that a severe anxiety and panic disorder qualified as a disability. ${ }^{1(1)}$ Such is the case for many people with mental illnesses who still have some ability to function in their occupational roles. The court failed to consider whether panic disorder, and the inability to handle a heavy teaching load of difficult courses, would impair Cadelli's ability to do many different kinds of jobs or the entire class of full-time teaching jobs. The court's failure to consider these alternatives deprived Cadelli of a chance to continue to work in some capacity at the school.

Both Forresi and Cadelli demonstrate the courts' pervasive unwillingness to recognize as disabilities mental illnesses that have profound effects on people's ability to work and on their employers' perceptions of their abilities. The single job exception was meant to be limited to

96. Id.

97. See DSM IV, supra note 71, at 405-10 (noting that, to be diagnosed with a phobia, one's symptoms must be more severe than the average person's fears).

98. 852 F. Supp. 789 (W.D. Ark. 1993), aff'd, 23 F.3d 1295 (8th Cir. 1994).

99. Id. at 797.

100. See id. at 798 . 
situations in which the barrier was peculiar to a single position. ${ }^{101}$ One example is where a baseball player develops a bad elbow such that he cannot pitch any longer, but he can perform virtually any other kind of work; his bad elbow is not a disability. ${ }^{102}$ However, impairments that preclude more than just a narrow set of jobs are disabilities under the $\mathrm{ADA}$. The inability to climb a large number of stairs or teach a large number of classes would seem to be barriers to more than just a narrow range of jobs, yet courts have bought into the employers' illogical argument that only one job is affected. ${ }^{103}$

\section{Episodic/Recurrent Disorders}

Another definitional issue that is especially important for people with mental illnesses is whether conditions that recur episodically or are characterized by periods of greater and lesser impairment will meet the definition of disability even when the person is symptom-free or in a less impaired period. The EEOC guidelines indicate that "temporary, non-chronic impairments of short duration, with little or no long term or permanent impact, are usually not disabilities," 104 while chronic impairments are generally considered disabilites. ${ }^{105}$ There is, however, a gap in this definition, making it unclear whether illnesses like Major Depression, which is often chronic but episodic, will be considered disabilities. According to the American Psychological Association's Diagnostic and Statistic Manual (DSM), the authoritative work on diagnosis of mental illnesses, over fifty percent of people diagnosed with Major Depression will eventually experience another Major Depressive episode and between twenty and thirty-five percent will experience a chronic course of the illness, with periods of remission and recur-

101. See Arlene Mayerson, Title I-Employment Provisions of the Americans with Disabilities Act, 64 TEMP. L. REv. 499, 506-08 (1991) (discussing the single job exception standard adopted by the ADA, which states that if an employer rejects an employee with a disability for a particular job on the basis of a disability, that person is considered "disabled" for purposes of the Act, whether or not the disability affects the person's ability to perform other jobs).

102. See 29 C.F.R. 1630 app. $\$ 1630.2(j)$ (1996).

103. Unfortunately, both Rehabilitation Act and ADA courts have read the single-job exception exceedingly broadly in all sorts of cases. See, e.g., Bolton v. Scrivner, 36 F.3d 939 (10th Cir. 1994) (injury to shoulder and feet, which limited an employee's ability to return to particular job, did not prevent him from performing a class of jobs or work generally), cert. denied, 115 S.Ct. 1104 (1995); Schluter v. Industrial Coils, 8 Nat'l Disability L. Rep. (LRP) I 197 (W.D Wis. 1996) (employer did not regard employee with diabetes and loss of eyesight as being unable to perform a range of jobs, only her particular job); Soileau v. Guilford of Maine, Inc., 8 Nat'l Disability L. Rep. (LRP) श 138 (D. Me. 1996) (employee with chronic psychiatric condition that limited his ability to interact with people for extended periods of time was not substantially limited in a major life activity), aff d, 105 F.3d 12 (1st Cir. 1997).

104. 29 C.F.R. 1630 app. $\$ 1630.2(j)$ (1996).

105. See id. (duration of impairment is a factor in determining if inpairment is substantially limiting and therefore a disability). 
rence. ${ }^{106}$ Similar variations in the course of illness are true for individuals with bipolar disorder, schizophrenia, and some types of anxiety disorder. ${ }^{107}$ Thus, it is not always clear what the expected course, chronic or not, will be during the initial episode of a mental illness.

For mental illnesses that are likely to become chronic and where, by definition, impairment is substantial, the court should presume that the diagnosis indicates a "disability" under the ADA. These illnesses would include, at the very least, Major Depression, bipolar disorder, schizophrenia, and severe anxiety disorders. The diagnostic criteria for each of these disorders include some requirement that the person show substantially impaired functioning. ${ }^{108}$ Thus, diagnosis of a major mental disorder by a trained mental health professional should be all that is necessary for a plaintiff to make a prima facie showing that she meets the ADA definition of disabled.

Employees whose illnesses have either remitted or do not raise this presumption may nevertheless show that they meet the definition of disability by fulfilling one of its two other prongs: having a record of a substantially impairing condition or being regarded as having such a condition. ${ }^{109}$ Again, this language tracks the language of the Rehabilitation Act. ${ }^{110}$ The Supreme Court, interpreting this section of the Rehabilitation Act, found that Congress intended to acknowledge that society's fears about disability can be as handicapping as limitations that result from impairing conditions. ${ }^{111}$ These modes of meeting the definition of disability can be particularly important for people with psychiatric disabilities. A record of disability can be important where the employer may not think of the condition as a disability, but rather as a moral failing or personal fault. Such thinking is exemplified in cases such as Franklin, where the court implied that the plaintiff's behavior and symptoms amounted to her own personal choice to behave that way. The belief that psychiatric illnesses are the fault of the impaired person or that they are something other than legitimate disabilities is a pervasive cultural myth, ${ }^{112}$ and one that the ADA seeks to combat. ${ }^{113}$

106. See DSM IV, supra note 71, at 325.

107. See id. at $235,242,246$ (panic disorder, social phobia, and obsessive compulsive disorder have a chronic course): SANDS, supra note 76 , at 184-85.

108. See DSM IV, supra note 71 , at $285,322,362,410,423,429$.

109. See 29 C.F.R. $\$ 1630.2$ (g)(2)-(3) (1996).

110. See 29 C.F.R. § 1614.203(a)(4)-(5) (1996).

111. See School Bd. of Nassau County v. Arline, 480 U.S. 273, 279 (1987).

112. See Perlin, Sanism, supra note 10, at 391-98.

113. See 42 U.S.C. \& 12101(b)(1)-(4) (1996). 


\section{B. Qualified Person with a Disability}

The second element a plaintiff must demonstrate to establish a case of prima facie discrimination under the $\mathrm{ADA}$ is that she is qualified for the position in question. The term "qualified individual with a disability" is defined in the EEOC regulations as "an individual with a disability who satisfies the requisite skill, experience, education and other job-related requirements of the employment position such individual holds or desires, and who, with or without reasonable accommodation, can perform the essential functions of such position."114 An important distinction between ADA cases and Rehabilitation Act cases is that, under the ADA, employees' qualifications are to be considered simultaneously with possible accommodations; the analysis of qualification cannot be separated from consideration of reasonable accommodations. By contrast, under the Rehabilitation Act there developed a line of cases, beginning with Southeastern Community College v. Davis, ${ }^{115}$ that required an employee to be qualified "in spite of" his or her disability, ${ }^{116}$ without regard to whether the disability could be accommodated. Thus, employees who could not qualify due to substantial physical or mental limitations could be excluded from employment, even if a reasonable accommodation would make it possible for them to do the job and do it well. ${ }^{17}$

Claimants under the Rehabilitation Act have found themselves caught in a "Catch-22" situation, having to claim an impairment that fits under the Act while also showing they are qualified for the job. In order to be considered persons with disabilities, they must plead facts that show that they are substantially limited by their impairment in one or more major life activities, or that they have a record of or are regarded as being so limited. ${ }^{118}$ Claimants must at the same time plead facts that demonstrate that they are fit for the job.

The Supreme Court substantially modified Davis in School Board of Nassau County $v$. Arline ${ }^{119}$ by holding that employers have a duty to consider reasonable accommodations. ${ }^{120}$ The Court in Arline found that tuberculosis and similar contagious diseases may qualify as disabilities under the Rehabilitation Act. ${ }^{121}$ In determining whether an individual

114. 29 C.F.R. $\S 1630.2(\mathrm{~m})(1996)$.

115. 442 U.S. 397 (1979).

116. Id. at 406 .

117. Part of the Supreme Court's and other courts' reluctance to require consideration of reasonable accommodation as part of the qualification inquiry may have resulted from confusion between reasonable accommodation and Title V1l affirmative action. For a discussion of this point, see Cooper, supra note 63, at 1434-41.

118. See 29 C.F.R. $\$ 1613.702$ (c)-(e) (1993).

119. 480 U.S. $273,287-89$ (1987).

120. See id.

121. See id. at 281. 
with a disability that may pose a direct threat to others is otherwise qualified for a position, courts must base their decisions on medical judgments as to the nature, severity, and duration of the risk the disability presents, the probability of transmission to others, and whether any reasonable accommodation can be made by the employer to reduce the risks identified. ${ }^{122}$ Thus, after Arline, the possibility of an effective reasonable accommodation must be considered when deciding whether an individual can perform a job. However, many courts have continued to follow the Davis reasoning and denied relief to individuals who may have been able to perform their jobs with reasonable accommodations. ${ }^{123}$

In order to determine whether a claimant is qualified for a position, a court must look at the essential functions of the job and whether the claimant can perform them. Depending on how essential functions are defined by courts, employees with psychiatric disabilities or with side effects from treatment of those disabilities may be seen as per se unqualified. Employers can plead a variety of defenses to the plaintiff's claim of qualification, including that termination was based on employee misconduct or that the employee posed a direct threat. As discussed below, these two defenses have been used extensively in cases where claimants have psychiatric disabilities.

\section{Essential Functions}

A key part of the qualification analysis is determining the essential functions of the job. The implementing regulations of the ADA define essential functions as "the fundamental job duties of the employment position the individual with a disability holds or desires." 24 Frequently, claimants with mental disabilities faced stumbling blocks when employers characterized the reasons for the adverse action taken against them as caused by the employee's conduct, not the disability. When the employee engages in conduct the employer finds unacceptable, the employee is seen as unable to fulfill the essential functions of the job due to the misconduct. Two main questions thus arise-what will constitute an essential function and what level of performance is necessary to fulfill such a function, particularly given a disabled employee's need for accommodation.

Under the Rehabilitation Act, courts often engaged in constricted analyses of what constituted an "essential function," holding that many

122. See id. at 288.

123. See, e.g., Mears v. Gulfstream Aerospace, 1995 WL 643111 (S.D. Ga. Sept. 5, 1995); Allen v. Stone, 1992 U.S. Dist. LEXIS 1008 (D.D.C. Sept. 30, 1992); Maryland Comm'n on Human Relations v. Mayor of Baltimore, 1 Nat'l Disability L. Rep. (LRP) II 256 (Md. Ct. Spec. App. 1991); See also Pushkin v. Regents, 658 F.2d 1372, 1387 (10th Cir. 1981).

124. 29 C.F.R. $§ 1630.2(n)(1)(1996)$. 
individuals with mental illnesses were incapable of fulfilling the essential functions of a position. ${ }^{125}$ For example, in Mackie $v$. Runyon, ${ }^{126}$ the court adopted without question the employer's characterization of working night shifts and erratic schedules as essential functions of the job. ${ }^{127}$ Because plaintiff's mental illness and the medication she took to control it made working nights and erratic shifts difficult, the court found her unable to perform these "essential functions." 128 In determining the "essential" nature of this scheduling pattern, the court only considered how the employer represented that the job had traditionally been done. ${ }^{129}$

Other courts have approached the analysis of essential functions with greater objectivity and nuance, as demonstrated in Overton $v$. Reilly. ${ }^{130}$ Overton was disabled due to his severe depression, which was mitigated by medication. He was hired by a unit of the EPA as a chemist. After about a month, his manager announced that all unit technical staff would have to take on new duties of writing permits, which required contact with the public. Overton's disability made contact with the public difficult, and he requested that his employer accommodate him by restructuring his duties so as to avoid in-person or phone contact with the public. ${ }^{131}$ The employer refused to consider this accommodation. The trial court granted summary judgment for the defendant on the issue of whether Overton was unable to perform essential job functions and thus not qualified. On appeal, the Seventh Circuit found that there was a genuine question about whether public contact was an essential function of the job. ${ }^{132}$ Some key considerations were whether public contact was part of the job description either when Overton was hired or when his manager announced the new policy; whether all other employees in the unit were required to have contact with the public; whether the function was such a marginal proportion of the workload that it could have been shifted to others in the unit; and whether some

125. See, e.g., Pesterfield v. Tennessee Valley Auth., 941 F.2d 437 (6th Cir. 1991); Gardner v. Morris, 752 F.2d 1271 (8th Cir. 1985); Matzo v. Postmaster Gen., 685 F. Supp. 260 (D.D.C. 1987), aff'd without op., 861 F.2d 1290 (D.C. Cir. 1988); Maryland Comm'n on Human Relations, 1 Nat'l Disability L. Rptr. (LRP) I 256; Baxter v. Wisconsin Dep't of Natural Resources, 3 Nat'l Disability L. Rep. (LRP) II 195 (Wis. Ct. App. 1991).

126. 804 F. Supp. 1508 (M.D. Fla. 1992). Though this case is post-passage of the ADA, it interprets the Rehabilitation Act and draws exclusively on Rehabilitation Act precedent and thinking. It is in some sense the quintessential example of what is wrong with courts' psychiatric disability jurisprudence both pre- and post-ADA.

127. See id. at 1511-12.

128. See id.

129. See id.

130. 977 F.2d 1190 (7th Cir. 1992).

131. In fact, the court noted that another member of the staff had no contact with the public. See id.

132. See id. at 1195 . 
accommodations, such as allowing Overton to communicate by mail with applicants or providing someone to make phone calls for him, would be reasonable. ${ }^{133}$ The court reversed and remanded for fuller consideration of the essential functions of the job and Overton's ability to fulfill them.

The court's approach in Overton is more in line with the letter and spirit of the ADA. Under the ADA, inquiry into a job's essential functions cannot end with the employer's assertion of what they are; an employer can no longer claim that the traditional way a job has been done establishes the position's essential functions. ${ }^{134}$ Nor can ability to fulfill the essential functions be considered in isolation from a possible accommodation. Rather, the ADA requires a more flexible and comprehensive view of "essential." Cases under the Rehabilitation Act that fail to take a critical look at these issues are inappropriate precedent for interpreting the ADA. Employers must show that the job must be done in a given way for some business-related reason, that the function is truly essential to the job and not merely marginal, and that no reasonable accommodation will allow the employee to perform the function. ${ }^{135}$

Courts should require the employer to spell out the essential functions and the reasons that certain purportedly essential functions are necessary for a position. Otherwise, employers may feel justified in making blanket exclusions or using criteria that screen out people with psychiatric disabilities, practices that are impermissible under the ADA. ${ }^{336}$

\section{Fulfilling Essential Functions-Employee Behavior/Misconduct}

Difficult questions of interpretation also arise when courts consider the degree of performance necessary to fulfill an essential function. If, for instance, an essential function of the job of clerk-typist is to follow instructions of supervisors in a pleasant manner, how far can an individual with a mental illness deviate before she is considered unable to fulfill that essential function? This question is especially difficult to answer when one considers that employees without mental disabilities may also not perform adequately on occasion, yet employers do not respond consistently. Further, if, as a general matter, it is essential that

133. See id.

134. See 29 C.F.R. \$ 1630.2(n)(3) (1996). Other factors include, “(ii) [w]ritten job descriptions prepared before advertising or interviewing applicants for the job; (iii) [t]he amount of time spent on the job performing the function... (v) [t]he terms of a collective bargaining agreement; (vi) [t]he work experience of past incumbents in the job; and/or (vii) [t]he current work experience of incumbents in similar jobs." Id.

135. See id.

136. See, e.g., 29 C.F.R. 1630 app. $\$ 1630.2(n)$ (1996) ("[1]f it is alleged that the employer intentionally selected the particular level of production to exclude individuals with disabilities, the employer may have to offer a legitimate, nondiscriminatory reason for its selection."). 
an employee not engage in misconduct, for what kinds of conduct may a disabled employee be disciplined, given that some conduct may be causally related to the disability? Answers to these questions should depend, in part, on the nature and severity of the misconduct and its amenability to accommodation. Courts, however, have been reticent to require employers to tolerate any degree of misconduct on the part of employees with psychiatric disabilities, despite the employers' failure to attempt accommodation and their clear disparate treatment of disabled employees.

In Carrozza v. Howard County, Maryland, ${ }^{137}$ the county government terminated an employee with bipolar disorder for alleged "insubordinate behavior and outbursts directed towards her supervisors." 138 The court's order does not elaborate as to the nature or severity of this behavior. We have no sense from the opinion of what exactly happened or whether the employer's response was in any way proportionate to the level of the "outbursts." Neither is there an indication that the behavior rose to the level of being threatening or hostile to other employees. What then does the ADA require in such a situation?

The ADA almost certainly requires that the employer give an employee with a disability the same amount of tolerance as it gives others without disabilities, as well as the same amount of discipline for misconduct as it gives others. ${ }^{139}$ To hold disabled individuals to a higher or more stringent standard would clearly be unlawful disparate treatment on the basis of disability. For this reason alone, cases such as Carrozza need to be reexamined in light of the ADA's stated purposes. ${ }^{140}$

However, the ADA may and should require more than just simple equal treatment. If the conduct of an individual is causally related to her disability, the employer should be required to attempt to accommodate that conduct or show that accommodating such conduct would be an undue hardship. ${ }^{141}$ Allowing employers to discharge employees with psychiatric disabilities on the basis of behavior caused by the disability would run contrary to the purposes of the ADA. The ADA explicitly

137. 847 F. Supp. 365 (D. Md. 1994), aff'd, 45 F.3d 425 (4th Cir. 1995).

138. Id. at 367.

139. See 29 C.F.R. 1630 App. § $1630.2(r)$ (1996) ("[A]ny D qualification standard ... must apply to all applicants or employees and not just to individuals with disabilities."); see also "EEOC Regulations for 29 C.F.R. Part 1630: Overview of Regulations, Section 1630.16 Specific Activities Permitted," 56 Fed. Reg. 35,733 (1991), codified at 29 C.F.R. § 1630) ("[t]hese revisions clarify that employers may hold all employees disabled... and nondisabled, to the same performance and conduct standards.").

140. See 42 U.S.C. § 12101(b)(1) (1996). "It is the purpose of this Act ... (1) to provide a clear and comprehensive national mandate for the elimination of discrimination against individuals with disabilities...." Id.

141. See infra notes 199-222 and accompanying text (discussing undue hardship/undue burden). 
grants protection to people with psychiatric disabilities. ${ }^{142}$ The ADA also recognizes that certain characteristics that would otherwise be legitimate reasons for adverse employment action may be symptoms of a protected disability. ${ }^{143}$ Psychiatric disabilities are diagnosed not on the basis of physiological tests or symptoms, but on the basis of behavior. ${ }^{144}$ Separating disability-caused behavior from the disability itself, therefore, is an impossible task. Permitting employers to act on the basis of psychiatric symptoms is akin to allowing the employer to claim that it is firing a person not because he has epilepsy but only because he has seizures. The behavior, while nominally separable from the disorder, is not logically separable. Just as in the case of epilepsy, the employer must accept the symptom as part of the disability and assess whether some reasonable accommodation can be made. If indeed the behavior is beyond accommodation, or such accommodation would work an undue hardship, the ADA then permits the employer to take the adverse action.

Again, Overton $v$. Reilly ${ }^{145}$ demonstrates a more appropriate and nuanced approach to employee misconduct, as the ADA requires. Though Overton dozed off at work due to side effects of his medication for depression, he still performed at a level that fulfilled the essential functions of his position. ${ }^{146}$ The court found that if Overton was able to perform at a satisfactory level and complete his work, his employer could not say that his occasional sleepiness constituted misconduct warranting termination. Employers must give employees with disabilities at least the same leeway that non-disabled employees are given, ${ }^{147}$ and in some situations more leeway when their "misconduct" is a direct consequence of their disability. Where, as in Overton, the employee's "misconduct" is a result of a disability, does not pose a harm to others, and does not substantially impact the quality of the work, the ADA requires that the employer accommodate the "misconduct."

Under the Rehabilitation Act, courts have found "peculiar behavior,"148 sensitivity to criticism, ${ }^{149}$ "loud . . insubordinate" behavior, ${ }^{150}$

142. See 29 C.F.R. $\S \S 1630.2(\mathrm{~h})(1)-(2)(1996)$.

143. See id. 1630 app. $\S 1630.2$ (h) ("[T]he definition [of disability] does not include common personality traits such as poor judgment or a quick temper where these are not symptoms of a mental or psychological disorder.") (emphasis added).

144. See DSM 111-R, supra note 71, at xxiii ("the definitions of [psychological] disorders are generally limited to descriptions or the clinical features of the disorders ... [which] consist of easily identifiable behavioral signs or symptoms.").

145. 977 F.2d 1190 (7th Cir. 1992).

146. See id.

147. Sce 29 C.F.R. $\$ 1630.2(\mathrm{n})(3)$ (vi)- (vii) (1996). There is, however, some question as to whether a claimant will always (or ever) be able to point to similarly-situated, non-disabled employees with whom such a comparison can be made. Proof of this type of disparate treatment is inevitably difficult for any person stating a claim of discrimination.

148. Matzo v. Postmaster Gen., 685 F. Supp. 260, 263 (D.D.C. 1987), aff'd without op., 861 F.2d 1290 (D.C. Cir. 1988). 
or other such conduct to be disqualifications to employment, even where the behavior is a direct result of the employee's mental illness. Courts are split on whether misconduct that stems from a disability can automatically disqualify the individual from the job. ${ }^{151}$ To be sure, the $\mathrm{ADA}$ does not require that the courts "erect an impenetrable barrier around the disabled employee, preventing the employer from taking any employment actions." 152 Still, all too many Rehabilitation Act cases confused behavior beyond the control of the individual with willful misconduct and gave individuals with psychiatric disabilities no protection against discrimination. In adopting the ADA, Congress recognized that discrimination against individuals with disabilities is a "serious and pervasive social problem"153 resulting from "characteristics ... beyond the control of [disabled] individuals and... stereotypic assumptions."154 Unfortunately, many cases under the Rehabilitation Act perpetuate stereotypical assumptions about people with mental disabilities. Some draw assumptions that people with mental illnesses require a virtually stress-free environment to work safely. ${ }^{\text {tss }}$ Others assume that behavior that might be routine for other employees signifies something more dangerous when exhibited by mentally ill employees. ${ }^{156}$ Other cases take a moralistic tone regarding the employee's mental illness ${ }^{157}$ and thereby blame individuals with psychiatric disabilities for "characteristics that are beyond the control of such individuals."1sB Such cases cannot be good law given Congress' ADA mandate to end stereotypic thinking about people with disabilities, and courts should not turn to those stereotypes for guidance in interpreting the ADA.

149. See Pesterfield v. Tennessee Valley Auth., 941 F.2d 437, 439 (6th Cir. 1991).

150. Carrozza v. Howard County, Md., 847 F. Supp. 365, 367 (D. Md. 1994), affd, 45 F.3d 425 (4th Cir. 1995).

151. Compare Teahan v. Metro-North Commuter Railroad Co., 951 F.2d 511 (2d Cir. 1991) (Rehabilitation Act case holding that discharge for misconduct resulting from alcoholism was discharge on basis of disability) with Little v. FBI, 1 F.3d 255 (4th Cir. 1993) (holding that employee can be lawfully terminated for misconduct even if arising from disability of alcoholism) and New/and v. Dalton, 81 F.3d 904 (9th Cir. 1996) (same).

152. Siefken v. Village of Arlington Heights, 65 F.3d 664, 666 (7th Cir. I995).

153. 42 U.S.C. $\$ 1210 I(2)(1996)$.

154. Id. \$ I2101(7).

155. See Pesterfield, 941 F.2d at 437; Magee v. Postmaster Gen., 903 F. Supp. 1022 (W.D. La. 1995); Carrozza, 847 F. Supp. at 365; Matzo, 685 F. Supp. at 260.

I56. See Crawford v. Runyon, 5 Nat'l Disability L. Rep. (LRP) I 363 (8th Cir. 1994); Carrozza, 847 F. Supp. at 365; Franklin v. United States Postal Service, 687 F. Supp. 1214 (S.D. Ohio 1988).

157. See, e.g., Franklin, 687 F. Supp. at I2I4; Margaret Hart Edwards, The ADA and the Employment of Individuals with Mental Disabilities, I8 EMPLOYEE REL. L. J. 347, 356 (I992/1993) (noting that the court in Franklin made a moral judgment about claimant's choice not to take medication, not an assessment of the impact of her disability).

158. See 42 U.S.C. \$ 121019(a)(7) (1996). 


\section{Direct Threat}

As part of the qualification analysis, courts under the Rehabilitation Act allowed employers to defend against a showing of qualification by claiming that the employee posed a direct threat in the workplace by virtue of a disability. In School Board of Nassau County v. Arline, ${ }^{159}$ the Supreme Court set the standard for determining what constitutes a direct threat under the Rehabilitation Act. In Arline, an employee with tuberculosis was discharged by the employer school board. The district court found that Arline was not qualified for the position. ${ }^{160}$ Justice Brennan, writing for the Supreme Court, reversed that decision, holding that the basic purpose of the Rehabilitation Act was "to ensure that handicapped individuals are not denied jobs or other benefits because of the prejudiced attitudes or the ignorance of others." 161 The Arline Court set forth three factors to consider when determining whether an individual's disability poses a direct threat: (1) the nature, duration, and severity of the risk, (2) the probability of harm, and (3) whether the employer could reasonably accommodate the employee's disability. ${ }^{162}$

The ADA adopted the Arline analysis in its entirety. The EEOC guidance regarding the "direct threat" defense requires that an employer demonstrate a significant identifiable risk of harm that is not speculative or remote, and a basis for the assessment of risk in objective factual evidence. ${ }^{163}$ Even if a genuine significant risk of substantial harm exists, the employer must consider whether the risk can be eliminated or reduced below the level of a "direct threat" by reasonable accommodation. ${ }^{164}$

As this Section demonstrates, however, courts have frequently short-circuited this more thorough analysis when interpreting the Rehabilitation Act, both before and after Arline. Employers have consistently used the direct threat defense, alleging that the claimant posed a threat to others, as well as to herself. Without cautious use of precedent and EEOC guidelines, courts risk incorrectly assessing employers' use of this defense.

\section{a. Threat to the Safety of Others}

Courts' interpretations of the direct threat provisions are especially important to individuals with mental illness because common stereotypes suggest that these individuals are much more likely to be violent

159. 480 U.S. 273, 288 (1987).

160. See 692 F.2d 1286 (M.D. Fla. 1988).

161. School Bd. of Nassau County v. Arline, 480 U.S. 273, 284 (1987).

162. See id. at 288.

163. Disability Discrimination, supra note 18 , at IV-8.

164. Id. 
than those without mental illness. This belief, however, is not supported by social science evidence, which indicates that individuals with major mental illnesses are not generally more dangerous than the average population. ${ }^{165}$ Though the belief in the heightened risk of violence of people with mental illnesses has been debunked by social science, it persists in our popular culture. Inevitably, these social stereotypes carry over into legal decision-making. ${ }^{166}$

Cases such as Franklin v. United States Postal Service ${ }^{167}$ present evidence of the pervasiveness of the stereotypes against the mentally ill. In that case, the Postal Service terminated the plaintiff for posing a "threat" to co-workers. Although the plaintiff's out-of-work behavior was troubling-the police removed her from the offices of two public officials-she had never behaved violently at work and had never been so much as disciplined or reprimanded by her employer for inappropriate behavior on the job. ${ }^{168}$ Yet, the court accepted the government's claim that the out-of-work behavior somehow constituted a threat to coworkers. To be fair to those with psychiatric disabilities, this logic would require employers to examine the out-of-work behavior of nondisabled employees as well, inquiring into their personal lives to ferret out all potentially violent employees. However, such a course seems almost certainly violative of employees' rights and is unlikely to provide a legitimate basis for terminating non-disabled employees. ${ }^{169}$

165. See John Monahan, Mental Disorder and Violent Behavior, 47 AM. Psycholocist 511, 517-19 (1992) (summarizing research that indicates that former mental patients' risk of violence is not appreciably higher than demographically similar members of their community who had never received psychological treatment, and that the magnitude of risk associated with mental disorder is quite modest compared to the risk associated with such characteristics as male gender, young age, and lower socioeconomic status); Jeffrey W. Swanson et. al., Violence and Psychiatric Disorder in the Community: Evidence from the Epidemiologic Catchment Area Surveys, 41 Hosp. \& Community PSYCHIATRY 761 (1990) (finding that individuals with a major mental diagnosis have mostly comparable rates of violence compared to those without a diagnosis; a far greater risk of violence is associated with alcoholism and substance abuse); Linda A. Teplin, The Criminality of the Mentally Ill: A Dangerous Misconception, 142 AM. J. PsYCHIATRY 593, 597-98 (1985) ("[T]he stereotype of the mentally ill as dangerous is not substantiated by our data...."). See also Stephen J. Morse, $A$ Preference for Liberty: The Case Against Involuntury Commitment of the Mentally $l l l, 70$ CAL.1F, L REv. 54, 62-63 (1982) (noting that persons with mental illnesses are probably no more dangerous than "normal" people and that mental disorder is both an over- and an underinclusive predictor of dangerousness, since most mentally ill people are not dangerous and many "normal" people are).

166. See Perlin, Sanism, supra note 10, at 379-80.

167. 687 F. Supp. 1214 (S.D. Ohio 1988).

168. See id. at 1216.

169. See, e.g., D.E. v. Department of the Navy, 721 F.2d 1165 (9th Cir. 1983) (reversing the discharge for sexual abuse of daughter because off-duty conduct was unrelated to on-the-job performance); In re Handy \& Harman Refining Div., 106 Lab. Arb. (BNA) 1049 (1996) (finding no just cause for discharge where employee committed acts substantiating donestic violence while offduty; employer must show nexus between employee's actions and ability to perform duties); In re Social Security Admin., 80 Lab. Arb. (BNA) 725 (1983) (finding no just cause for termination where employee engaged in illegal sexual activity off-duty). Of course, most employees are at-will employees and could therefore be fired for less than just cause. As it has been said, when you are an 
Where claimants have psychiatric disabilities, courts should carefully scrutinize questions of direct threat. Such scrutiny has not been the norm. In Palmer v. Circuit Court, ${ }^{170}$ the court found that the plaintiff, who suffered from a delusional disorder and depression, posed a direct threat to the safety of her co-workers. ${ }^{171}$ The court based its finding of direct threat on a dispute that arose between the plaintiff and a co-worker. ${ }^{172}$ Although the plaintiff testified that the co-worker threatened her with bodily harm, her account was uncorroborated. What was corroborated about the dispute was that the plaintiff said to the coworker, "'[L]ook, if you don't leave me alone, I'm going to throw you out the window." between the plaintiff and a different co-worker where the plaintiff allegedly said that she was "'so sick' of [her former supervisor] she 'could just kill her."'174 Such statements are arguably commonplace in many work settings, but when issued from the mouth of an individual with a mental disorder, suddenly gain new significance. Again, to treat disabled employees fairly, courts need to ask whether these statements alone constitute enough evidence of threat to treat a disabled employee who says them differently from a non-disabled speaker. When an employee with a mental disorder is alleged to pose a direct threat, the ADA requires that the employer identify the specific behavior that constitutes a threat and then analyze the behavior using the Arline criteria. ${ }^{175}$ To grant summary judgment based on the quoted statements alone, without taking into account their context, indicates that the Palmer court engaged in heuristic, stereotype-based reasoning.

In a situation similar to Palmer, the trial court in Crawford $v$. Runyon ${ }^{176}$ granted summary judgment to an employer who alleged that a worker diagnosed with depression and paranoid schizophrenia had threatened to harm or kill a supervisor. ${ }^{177}$ The employee denied threatening anyone and submitted evidence that his supervisor had circulated a newspaper article about a psychotic man who killed several people, with the supervisor's handwritten notation in the margin suggesting that the employee had the same illness as the killer. Still, the trial court found no triable issues of fact as to whether the employee was termi-

at-will employee, you can be fired for any reason, so long as it is not a discriminatory reason. The harder question is raised when the reason, as here, is related to someone's disability.

170. 905 F. Supp. 499 (N.D. 11l. 1995).

171. See id.

172. See id. at 508 .

173. Id. at 501 .

174. Id. at 502 .

175. See 29 C.F.R. 1630 app. \& 1630.2(r) (1996).

176. See 5 Nat'1 Disability L. Rep. (LRP) II 363 (8th Cir. 1994 ) (discussing the district court's analysis).

177. See id. at 364. 
nated for discriminatory reasons. ${ }^{178}$ On appeal, the Eighth Circuit reversed the judgment on plaintiff's Rehabilitation Act claim, requiring the trial court to make an individualized factual determination of whether the employee posed a threat to his co-workers. ${ }^{179}$ The Eighth Circuit in Crawford took the necessary care to avoid a decision based on stereotypes about people with mental illnesses, rather than simply assuming that violence always follows from a psychiatric diagnosis.

Courts have also struggled with the question of whether those with mental illness pose a direct threat to others because of their illness' "contagious" effects. A prominent pre-Arline case under the Rehabilitation Act, Doe v. Region 13 Mental Health-Mental Retardation Commission, ${ }^{180}$ upheld the district court's judgment, notwithstanding the jury's verdict in favor of the plaintiff, where the employer claimed that Doe's depression and suicidal ideation might be transmitted to the patients whom she counseled. ${ }^{181}$ In Region 13, Doe claimed the medical director of the region, who had just learned the specifics of Doe's illness from a colleagne, gave Doe the option to resign or take a "long-term leave for hospitalization with no job upon her 'return."'182 This was the only reasonable accommodation attempted. Yet the court held that the employer's termination of Doe by reason of her disability was justified, despite her "outstanding" performance evaluations by her supervisors and an exemplary work record. ${ }^{183}$ The Fifth Circuit decided Region 13 without the benefit of Arline's clearer standard of direct threat. Under the Arline standard adopted by the ADA, the Region 13 court would have been required to find that Doe's disability constituted a substantial risk of harm and that no accommodation would reduce that risk of harm. Had the Region 13 court assessed the degree of the risk and the possibility of an accommodation, such as increasing the existing supervision and monitoring of Doe's work, the court would almost certainly have decided in Doe's favor. Courts should reject precedent offered to suggest that the ADA requires anything less than a showing of substantial risk of harm ${ }^{184}$ or that the risk can be assessed without considering possible accommodations to reduce it.

178. See id.

179. See id.

180. 704 F.2d 1402 (5th Cir. 1983).

181. See id. at 1412.

182. Id. at 1406 .

183. Id. at 1404 .

184. At least one Rehabilitation Act case indicated that a less-than-substantial risk is enough. In Doe v. New York University, 666 F.2d 761, 777 (2d Cir. 1981), the Second Circuit stated that even a "minimal" risk of harm justified rejecting a medical school applicant with a mental illness. 


\section{b. Risk of Self-Harm}

Courts interpreting the ADA must also decide whether "direct threat" includes risk of harm to the employee with a disability. Though the Region 13 court raised the issue of risk to self without directly addressing it, other courts have at least partly based their decisions on the issue of potential risk to the employee himself. ${ }^{185}$ The legislative history does not state that Congress intended threats to self to be included in the definition of "direct threat." 186 Similarly, Department of Justice regulations under $\mathrm{ADA}$ Title II do not include threats to self, yet EEOC regulations made pursuant to Title I provide that direct threat is "a significant risk of substantial harm to the health or safety of the individual or others that cannot be eliminated or reduced by reasonable accommodation." 187 Though some commentators suggest that the EEOC regulation is inconsistent with the statutory language of the ADA and will not withstand scrutiny, ${ }^{188}$ even as currently stated, given the "substantial risk" language, the regulation must be interpreted narrowly. The EEOC regulations themselves note that paternalistic concerns about exacerbation of a disability cannot be used to show direct threat to self and thus disqualify an individual with a disability. ${ }^{189}$

Rehabilitation Act precedent that suggests that individuals with mental illness need a "stress-free" environment to work safely ${ }^{190}$ or that individuals cannot assess the level of acceptable risk to their own health contain too broad a reading of the direct threat provisions and should not be followed. For example, in Magee v. Postmaster General, ${ }^{191}$ a postal employee was terminated on the basis of a fitnessfor-duty examination that indicated that his disability rendered him unable to perform safely the essential functions of his job..$^{192}$ The court found that the post office had no position that would provide the plaintiff with the "quiet, solitary, and stress-free environment" that the court

185. See, e.g., Gardner v. Morris, 752 F.2d 1271, 1281 (8th Cir. 1985) (finding that Army Corps of Engineers "would have acted irresponsibly if it had permitted [plaintiff] to complete his Saudi Arabia assignment because [plaintiff's] medical condition jeopardized his own safety as well as that of fellow workers.").

186. See H.R. Rep. No. 485-101, at 45-46 (1990) (others only); H.R. Rep. No. 485-101, pt. 2, at 56-57, 73-74 (1990) (others only); S. Rep. No. 116-101, at 27 (1989) (others only).

187. 29 C.F.R. $\$ 1630.2(r)$ (1996).

188. See, e.g., Parry, supra note 3 , at 102.

189. See 29 C.F.R. 1630 app. $§ 1630.2(r)$ (1996).

190. See Pesterfield v. Tennessee Valley Authority, 941 F.2d 437, 441 (6th Cir. 1991); Carrozza v. Howard County, Md., 847 F. Supp. 365, 368 (D. Md. 1994) (holding that the ADA does not require that an employer restructure a job so as to eliminate its "inherent stressors"), aff"d, 45 F.3d 425 (4th Cir. 1995); Matzo v. Postmaster Gen., 685 F. Supp. 260, 264 (D.D.C. 1987), aff d without op., 861 F.2d 1290 (D.C. Cir. 1988).

191. Magee v. United States Postal Serv. 903 F. Supp. 1022 (W.D. La. 1995), aff'd without op., 79 F.3d 1145 (5th Cir. 1996).

192. See id. at 1024. 
presumed he needed. ${ }^{193}$ In reaching its conclusion, the court relied upon testimony by plaintiff's psychiatrist that the plaintiff had difficulty working in groups and experienced stress in his current job arrangement. ${ }^{194}$ Despite the ADA's imposition on the employer of the duty to consider accommodations, the psychiatrist did not proffer a reasonable accommodation, nor did the employer inquire as to whether the psychiatrist believed one was possible. Without requiring any showing of plaintiff's actual limitations or any attempt to arrive at a possible accommodation, the court assumed that the employer was well within its rights to remove a "stressed-out" employee.

By contrast, courts have shown themselves to be less apt to make rash judgments about the ability of physically disabled people to tolerate stress. In Pushkin v. Regents of the University of Colorado, ${ }^{195}$ a doctor with multiple sclerosis was rejected from a residency program based in part on the admissions committee's belief that people with multiple sclerosis have difficulty withstanding stress. The court refused to allow the admissions committee to act on stereotypical beliefs about plaintiff's disorder rather than an individualized factual inquiry with respect. to the plaintiff. ${ }^{196}$ As the court so aptly stated, discrimination against people with disabilities "often occurs under the guise of extending a helping hand or a mistaken, or restrictive belief as to the limitations of handicapped persons."197

Courts interpreting the ADA should follow the lead of the Pushkin court and the Ninth Circuit, which subjects employers' harm-to-self defenses to "rigorous scrutiny."198 The ADA requires that employers and courts make judgments based on more than stereotypes. Rehabilitation Act decisions that fail to meet this requirement are not appropriate precedent for interpreting the ADA.

\section{Reasonable Accommodation and Undue Burden}

Both the Rehabilitation Act and the ADA require that employers make reasonable accommodations to allow people with disabilities an equal employment opportunity. Accommodations are considered reasonable if they do not impose an undue burden on the employer. Rehabilitation Act case law analyzed reasonable accommodation and undue burden in a variety of different ways, some of which are no

193. Id. at 1027.

194. See id.

195. 658 F.2d 1372, 1387 (10th Cir. 1981).

196. See id.

197. Id. at 1385.

198. Bentivegna v. United States Dep't of Labor, 694 F.2d 619, 623 (9th Cir. 1982) (holding that the dismissal of a diabetic construction worker on the basis of potential self-harm does not satisfy heightened scrutiny). 
longer valid under the ADA. Employers and courts have demonstrated some confusion about how to conceptualize accommodations, particularly when the disability to be accommodated is psychiatric in nature. Courts have also refused to recognize some proposed accommodations as reasonable, even though the accommodations are now explicitly validated under the ADA. Examples include reassignment and provision of auxiliary aids and services. Moreover, the ADA's changes in the definition of undue burden, and in the allocation of proof of such a burden, have altered the landscape in important ways for claimants with psychiatric disabilities.

The EEOC defines reasonable accommodations as

[m]odifications or adjustments to a job application process ... the work environment, or to the manner or circumstances under which the position held or desired is customarily performed, that enable a qualified individual with a disability to perform the essential functions of that position [or] ...to enjoy equal benefits and privileges of employment as are enjoyed by its other similarly situated employees without disabilities. ${ }^{199}$

The regulations give examples of the types of adjustments that may constitute a reasonable accommodation, including job restructuring, reassignment, provision of qualified readers and interpreters, and acquisition or modification of equipment, training materials, and policies. ${ }^{200}$

Employers need not provide accommodations that are not "reasonable," that is, accommodations that impose an "undue burden" on the employer, either economically or in terms of workplace disruption. ${ }^{201}$ Undue burden is defined in the regulations as "significant difficulty or expense incurred by [an employer]."202 Analysis of undue burden requires consideration of difficulty or expense in light of the net cost to the employer, taking into account outside funding, available tax credits for reasonable accommodations, ${ }^{203}$ and the overall financial resources of the employer, and the overall impact on the employer's operation. ${ }^{204}$

Under the Rehabilitation Act, courts have grappled with the concepts of reasonable accommodation and undue burden. One of the first and most important cases to interpret the Rehabilitation Act and its limits was Southeastern Community College v. Davis. ${ }^{205}$ The Davis Court unanimously held that the Rehabilitation Act did not forbid

199. 29 C.F.R. § $1630.2($ (o)(1)(i)-(iii) (1996).

200. See id.\$1630.2(o)(2)(ii).

201. See id. \& 1630.2(p)(1)-(2).

202. Id. \&1630.2(p)(1).

203. See Disabled Access Credit, IRS Form 8826.

204. See 29 C.F.R. \& 1630.2(p)(2)(i)-(v) (1996).

205. 442 U.S. 397 (1979). 
professional schools from imposing reasonable physical qualifications for admission to their training programs. ${ }^{206}$ If a person is unable to perform reasonable physical tasks related to legitimate educational requirements that are not amenable to accommodation, excluding that person from a program does not constitute actionable discrimination under the Rehabilitation Act. ${ }^{207}$ The complainant was a licensed practical nurse (LPN) who sought certification as a registered nurse through the community college's program. She had a hearing disability that required use of a hearing aid and lip-reading in order to understand others' speech, a task that would be impossible in the training program's surgical rotation where participants would be wearing surgical masks. ${ }^{208}$ The school also determined that the complainant's condition would make it unsafe for her to care for patients, despite the fact that she had done so as a LPN. ${ }^{209}$ The Supreme Court reversed the lower court's holding that the school should consider Davis' qualifications without regard to her disability. Writing for the Court, Justice Powell noted that

[s]ection 504 by its terms does not compel educational institutions to disregard the disabilities of handicapped individuals or to make substantial modifications in their programs to allow disabled persons to participate. Instead, it requires only ... that mere possession of a handicap is not a permissible ground for assuming an inability to function in a particular context. ${ }^{210}$

The Court rejected Davis' contention that the school had an obligation to provide her individual supervision that would eliminate the need for oral communication. This modification, or the elimination of the clinical rotation, would have imposed too great a burden on the school, and would have forced them to fundamentally alter their program. ${ }^{211}$ Though the Court acknowledged the fine line between lawfully refusing to alter a program and unlawfully discriminating against people with disabilities, ${ }^{212}$ it concluded that Davis' situation fell into the former category.

The Court's decision in Davis was used to limit the reach of the Rehabilitation Act and paved the way for regulations providing that accommodations do not require a lowering of standards and that compliance with regulations should be assessed through the application of a

206. See id. at 414 .

207. See id. at 409-10.

208. See id. at 403 .

209. See id. at 401 n.1.

210. Id. at 405.

211. See id. at 409-10.

212. See id. at 412-13. 
cost-benefit principle. ${ }^{213}$ Moreover, as a result of Davis, many lower courts never reached a reasonable accommodation analysis because plaintiffs could not satisfactorily demonstrate that they could perform essential job functions in spite of their disabilities. ${ }^{214}$

Eight years later, in School Board of Nassau County v. Arline, ${ }^{215}$ the Court modified Davis and explicitly incorporated a reasonable accommodation analysis into the "otherwise qualified" question. ${ }^{216}$ Under Arline, the possibility of an effective reasonable accommodation must be considered when deciding whether an individual can perform a job. As previously discussed, this is the position subsequently adopted by the ADA - that individuals are qualified if they meet the skill and educational requirements and, with or withont accommodation, they can perform the essential functions of the job. ${ }^{217}$ However, the $\mathrm{ADA}^{\prime}$ 's position is at odds with the Davis standard used by courts in many cases decided under the Rehabilitation Act. Cases that took the Davis approach and did not consider accommodation simultaneously with qualification inadequately analyzed an individual's qualifications and an employer's responsibility to reasonably accommodate a disability under the ADA.

It is important to note that even under the Davis standard, some courts considered the possibility of reasonable accommodation when determining qualification. In a few notable cases, the courts found that accommodations such as hearing aids, ${ }^{218}$ modifications of the working environment for people with limited mobility, ${ }^{219}$ restructuring a job by reassigning certain non-essential dnties to other employees, ${ }^{220}$ and provision of readers for blind employees ${ }^{221}$ should be provided and taken into account in determining whether the employees in question were "otherwise qualified" for their positions. Yet in the context of claims based on psychiatric disabilities, courts interpreting the Rehabilitation

213. See Stephen L. Percy, Disability, Civil Rights, and Public Policy 95 (1989).

214. See Loretta K. Haggard, Reasonable Accommodation of Individuals with Mental Disabilities and Psychoactive Substance Use Disorders Under Title I of the Americans with Disabilities Act, 43 WASH. U. J. URB. \& CONTEMP. L. 343, 353 (1993).

215. 480 U.S. $273,287-89$ (1987).

216. See id. at 288.

217. See 29 C.F.R. § 1630.2(m) (1996); Disability DisCRimination, supra note 18, at I-2.

218. See Strathie v. Department of Transp.,716 F.2d 227 (3d Cir. 1983) (overturning grant of summary judgment where employer suspended hearing-impaired bus driver because employer failed to show no reasonable accommodation was possible).

219. See Prewitt v. United States Postal Serv., 662 F.2d 292 (5th Cir. 1981) (overturning grant of summary judgment where postal service refused to hire disabled applicant because the employer failed to show that reasonable accommodation was not possible).

220. See Davis v. Frank, 711 F. Supp. 447 (N.D. Ill. 1989) (finding that assigning telephone answering duties to other employees to allow deaf postal clerk to maintain employment is not an undue burden).

221. See Nelson v. Thornburgh, 567 F. Supp. 369 (E.D. Pa. 1983), aff d without op., 732 F.2d 146 (3d Cir. 1984). 
Act, even after Arline, have generally been unwilling to consider reasonable accommodations as a part of the qualification analysis. ${ }^{222}$

\section{The Concept of Accommodation}

Accommodations for people with psychiatric disabilities may be harder to conceptualize than accommodations for those with physical disabilities, where designing an accommodation is generally seen as a physical or mechanical solution to a physical barrier or mechanical problem. Such conceptualization problems, coupled with perceived barriers to simple accommodations under the Rehabilitation Act, have hindered many mentally ill employees from obtaining relief in the courts.

Accommodations that are not of a physical nature may also be perceived less as a necessary tool to allow the individual to work than as special or easier treatment of the individual with a psychiatric disability. Non-physical accommodations such as flexible scheduling, time off for therapy, or increased supervision and positive feedback are more likely than physical accommodations to be seen as favorable treatment or as something everyone will want if they can get it. This perception of nonphysical accommodations as less serious is exemplified in the opinion of the court in Carrozza. ${ }^{223}$ Carrozza, who suffered from bipolar disorder, averred that she could have performed her job in a satisfactory manner if her employer had provided her with any of several possible accommodations, including changing her work schedule to alleviate stressful periods, relocating her to a department away from a particularly demanding supervisor, and modifying training materials for a new computer system. ${ }^{224}$ The court, granting summary judgment to the employer, criticized the plaintiff's proffered suggestions as "fuzzy ... alterations... designed to strip [the job] of its inherent stresses." 225 The Carrozza court seems to misinterpret a needed solution to the employee's problem as an employee's request to be coddled.

222. See, e.g., Pesterfield v. Tennessee Valley Auth., 941 F.2d 437 (6th Cir. 1991) (laborer with depression not otherwise qualified, and no accommodations considered because employer and court assumed that none would be effective); Fields v. Lyng, 705 F. Supp. 1134 (D. Md. 1988) (if labor negotiator with anxiety and borderline personality disorder only qualified but-for his disability, he is not otherwise qualified), aff'd without op., 888 F.2d 1385 (4th Cir. 1989); Doe v. Region 13 Mental Health-Mental Retardation Comm'n, 704 F.2d 1402 (5th Cir. 1983) (mental health worker with mental disability not otherwise qualified because she has such a disability).But cf. Overton v. Reilly, 977 F.2d 1190 (7th Cir. 1992) (employer could restructure job to allow employee with emotional illness to perform only tasks not involving direct contact with the public). This is not to suggest a grand scheme to only subject claimants with mental disabilities to the Davis standard after Arline. However, insofar as courts continued to rely on Davis, those precedents are not appropriate and may be difficult to separate from those following Arline.

223. See Carrozza v. Howard County, Md., 847 F. Supp. 365 (D. Md. 1994).

224. See id. at 368 .

225. Id. 
Since the court does not discuss whether the employer engaged in an attempt to solve the problem by other means, there is no real evidence by which to judge the reasonableness of the employee's request. However, the court's languages implies that relieving stress on the job is not an appropriate accommodation. It would be surprising if the court took the same attitude toward, for example, a physically disabled person's request that the employer alleviate the "stress" of not being able to reach the shelves in her office, or a hearing-impaired employee's complaint about the "stress" of not being able to use a phone that was not TDD-equipped. Because courts have difficulty conceptualizing the types of limitations people with mental illnesses face and the types of solutions available to allow them to work, they may perpetuate the discrimination people with mental illnesses face in the workplace.

Accommodations offered by the employer must, by definition, be modifications that will actually allow the employee to perform the essential functions of the job. Though the point seems obvious, it is one that may have escaped courts interpreting the Rehabilitation Act. For example, in Matzo v. Postmaster General, ${ }^{226}$ the employer terminated a worker with bipolar disorder shortly after her two-month hospitalization, and offered to "accommodate" her by converting her involuntary termination to a resignation. ${ }^{227}$ The court found that the offer was a reasonable accommodation and dismissed the plaintiff's complaint. ${ }^{228}$ Clearly, this "accommodation" was not one that would have allowed the plaintiff to fulfill the essential functions of the job, nor was it arrived at through an individualized inquiry into the plaintiff's skills and limitations. This type of analysis is inappropriate under the ADA and demonstrates a disdain for individuals with psychiatric disabilities.

\section{Reassignment}

The ADA removed a perceived barrier to accommodation encountered under the Rehabilitation Act by requiring employers to consider reassigning a disabled employee as a reasonable accommodation. ${ }^{29}$ Several Rehabilitation Act cases held that reassigument was not a reasonable accommodation. ${ }^{230}$ In Shea $v$.

226. See 685 F. Supp. 260 (D.D.C. 1987), aff'd without op., 861 F.2d 1290 (D.C. Cir. 1988).

227. See id. at 264.

228. See id.

229. 29 C.F.R. § 1630.2 (o)((2)(ii) (1996).

230. See, e.g., Shea v. Tisch, 870 F.2d 786 (1st Cir. 1989) (holding reassignment irrespective of seniority not required by the Rehabilitation Act); Mackie v. Runyon, 804 F. Supp. 1508 (M.D. F. 1992) (holding that reassignment did not qualify as a reasonable accommodation); Fields v. Lyng, 705 F. Supp. 1134 (D. Md. 1988) (holding that the government need not tranfer or reasign an employee to accommodate his anxiety disorder), aff $d$ without op., 888 F.2d 1385 (4th Cir. 1989); Carty v. Carlin, 623 F. Supp. 1181 (D. Md. 1985) (holding that duty to accommodate only contemplates accommodation of employee in present position, not reassignment or transfer); see also Maryland 
Tisch, ${ }^{231}$ Shea, a disabled Vietnam veteran living with an anxiety disorder, was a long-time postal employee with a good work record. After a series of medically-related absences, the postal service attempted to terminate him. 'Shea's psychologist recommended that Shea be reassigned to reduce the stress of the long commute Shea needed to take to get to his duty station, assuring the postal service that Shea's absenteeism would improve with this accommodation. In response, the postal service temporarily assigned Shea to an office closer to his home and recommended that he bid on permanent positions that he would normally be eligible for given his seniority status. The one position Shea applied for was denied due to his absences at his former position. The postal service did nothing further to accommodate Shea, and after almost a year of allowing Shea to look for another position, terminated him. On appeal from summary judgment for the employer, the First Circuit affirmed the district court's finding that the postal service could not reassign Shea to a job location that would accommodate his disability because to do so would violate a collective bargaining agreement. ${ }^{232}$

Shea raises two issues-what is a reasonable accommodation, and what would make an otherwise reasonable accommodation unreasonable. The ADA now specifically mandates that reassignment to a vacant position can be a reasonable accommodation. ${ }^{233}$ With regard to the second question, the ADA's regulatory guidance states that the existence of a collective bargaining agreement, while relevant to the determination of whether such an accommodation would be an undue hardship, is not dispositive. ${ }^{234}$ Consequently, cases like Shea, which treat collective bargaining agreements as absolute barriers to reassignment without any further examination of reasonableness or burden, ${ }^{235}$ are

Comm'n on Human Relations v. Mayor and City Council of Baltimore, 1 Nat'l Disability L. Rep. (LRP) I 256 (Md. Ct. Spec. App. 1991) (using Rehabilitation Act precedent to construe Maryland anti-discrimination statute as not requiring altermative employment of police officer with mental disability).

231. 870 F.2d 786 (1st Cir. 1989).

232. See id. at 789 .

233. See 29 C.F.R. $\S 1630.2(0)((2)(i i)$ (1996). At least one court has affirmed the reasonableness of accommodation by reassignment under the ADA. See Wood v. County of Alameda, No. C94-1557, 1995 WL 705139, at *16 (N.D. Cal. Nov. 17, 1995) (employee with psychiatric disorder requesting reassignment to a different supervisor).

234. See Disability Discrimination, supra note 18 , at III-14.

235. See Carter v. Tisch, 822 F.2d 465 (4th Cir. 1987) (duty to accommodate cannot defeat a collective bargaining agreement). Use of collective bargaining agreements continues to be a contentious issue under the ADA. Cases under the ADA have not faithfully followed the EEOC's guidance on this matter. See, e.g., Eckles v. Consolidated Rail Corp., 94 F.3d 1041 (7th Cir. 1996) (holding that ADA does not require a reasonable accommodation that would violate a seniority system), petition for cert. filed, Nov. 12, 1996. 
inadequate for interpreting the $\mathrm{ADA}$ 's requirement of reasonable accommodation.

Further, cases like Shea that do not scrutinize an employer's alleged attempts to accommodate an employee in order to determine whether the employer has engaged in a "flexible, interactive process that involves both the employer and the qualified individual with a disability"2336 violate the clear requirements of the ADA. Under the ADA, failure to accommodate a known physical or mental limitation of an otherwise qualified individual is unlawful unless the employer can demonstrate undue burden. ${ }^{237}$ Rehabilitation Act cases that suggest that employers need not consider accommodations are therefore absolutely inappropriate precedent for interpreting the ADA.

Thus, for example, the opinion of the court in Pesterfield $v$. Tennessee Valley Authority ${ }^{238}$ does not subject the employer's defense to the kind of analysis that the ADA requires. The court in Pesterfield affirmed a decision that an employer could not accommodate his employee's anxiety and depression. The court did not require the employer to make an individualized factual showing of impossibility or an attempt to accommodate. Relying on the diagnosis and statement of the plaintiff's physician, the court concurred with the employer's termination. The trial court found that it was "unable to imagine any jobs where plaintiff could be immunized from any criticism or other normal stresses of the workplace, ${ }^{3239}$ which both the court and employer assumed that the plaintiff would require. In fact, this is not the accommodation that plaintiff or his physician requested, nor was it clear that it would be the only accommodation that would allow the plaintiff to do his job. Under the ADA, the employer would be required at least to consider possible accommodations in deciding whether the employee met the qualifications for his position.

Similarly, the First Circuit's decision in August v. Offices Unlimited $^{240}$ should not stand under the ADA. In August, the court found that the plaintiff's qualification for insurance on the basis of "total disability" meant that he could not work at all, regardless of any accommodation. The court concluded that the employer had no duty to consider plaintiff's proposed accommodations. This is not the

236. See Disability Discrimination, supra note 18 , at B-43.

237. See 29 C.F.R. 1630.9(a) (1996).

238. 941 F.2d 437, 441-42 (6th Cir. 1991).

239. Id. at 441. The employer focused, to the detriment of the plaintiff, on one sentence in his doctor's evaluation: "[i]f there is the slightest hint of rejection or criticism, [the plaintiff] becomes extremely anxious and depressed." Id. at 439. Though the context of the letter, and plaintiff's desire to retum to work, indicate that the physician's statement was misinterpreted by the employer, the statement indicates that physicians may have to examine their own biases regarding individuals with disabilities and work.

240. 981 F.2d 576 (1st Cir. 1992). 
individualized inquiry that the ADA requires. In fact, the First Circuit has recently revisited August and determined that an application for disability benefits is not a bar to reasonable accommodation, ${ }^{241}$ the correct approach under the ADA.

Cases like Shea, Pesterfield, and August demonstrate the limits of Rehabilitation Act precedent for interpreting such key ADA provisions as the duty to provide reasonable accommodation. ${ }^{242}$ Where cases engage in slipshod analysis, based on stereotypes and unproven assumptions about individuals with mental illnesses, both the statutory requirements and the nondiscriminatory spirit of the law are violated. Already, courts interpreting the ADA have fallen prey to this stereotypeladen analysis. ${ }^{243}$ To be true to the letter and purpose of the law, courts will have to be cautious in their reasoning and their reliance on Rehabilitation Act precedent.

\section{Accommodating Misconduct}

Under Rehabilitation Act precedent, courts have routinely rejected arguments that employee "misconduct," even where it is a direct result of the person's disability, must be accommodated. These misconduct cases invariably involve individuals with either substance abuse problems or mental illnesses. ${ }^{244}$ Thus, in Fields v. Lyng, ${ }^{245}$ a labor negotiator whose psychiatric disability resulted in several shoplifting convictions was deemed not otherwise qualified for the position and not capable of being qualified by any accommodation of the employer. ${ }^{246}$ This misconduct was seen as impairing Fields' integrity and credibility, functions apparently "essential" to his position within the meaning of the Act. ${ }^{247}$ Fields' work was consistently rated satisfactory, and the misconduct occurred only when he was not working. However, the district court found that "[h]e would only be qualified but for his handicap,

241. See D'Aprile v. Fleet Services Corp., 92 F.3d 1 (1st Cir. 1996).

242. See also Guice-Mills v. Derwinski, 967 F.2d 794, 797-98 (2d Cir. 1992) (holding that employer need not attempt to accommodate an employee whose disability made it impossible to start her shift at 7:30 a.m.); Allen v. Stone, No. 89-3007, 1992 U.S. Dist. LEXIS 1008 (D.D.C. Jan. 30, 1992) (finding that the agency could not make a reasonable accommodation to plaintiff's condition because it could not "guarantee that [plaintiff"s] superiors would not impose constraints that [plaintiff] would not find unreasonable," id. at *10, and therefore no attempt to accommodate was necessary).

243. See, e.g., Carrozza v. Howard County, Md., 847 F. Supp. 365, 368 (ruling against plaintiff with bipolar disorder whose requested reasonable accommodations were deemed "fuzzy, possible alterations of her job designed to strip it of its inherent stresses"), aff'd, 45 F.3d 425 (4th Cir. 1995).

244. See Lee, supra note I8, at 230-33.

245. 705 F. Supp. 1134 (D. Md. 1988).

246. See id. at 1137. Kleptomania is not a covered disability under the ADA. See 42 U.S.C. $\$ 12111(b)(2)$ (1996). However, it has not been eliminated from the Rehabilitation Act's coverage. See Haggard, supra note 214, at 358 n.80.

247. See Fields v. Lyng, 705 F. Supp. 1134, 1137 (D. Md. 1988). 
and as such, he is not entitled to reasonable accommodation.".248 Whether we think the result of this case is right or not, the analysis the court engaged in is not what the ADA would require. Though decided after Arline, Fields did not follow the Arline analysis and consider possible accommodations simultaneous to determining the plaintiff's qualifications.

Fields also implies that misconduct is never required to be accommodated, a principle at odds with the ADA's nondiscrimination mandate. ${ }^{249}$ Where behavior termed "misconduct" is a result of a psychiatric disability, employers should be required to accommodate the behavior so long as such accommodation is not an undue burden. If reasonable accommodation is not required, employers will have strong incentives to include more and more behavior under the rubric of "misconduct," removing their actions from scrutiny. As previously stated, unusual behavior is intrinsically tied to psychiatric disorder. If employers are permitted to make blanket exclusions on the basis of unusual behavior without considering its relationship to disability or the possibility of accommodating it, individuals with psychiatric disabilities will find little protection in the ADA.

\section{Auxiliary Aids and Services}

Few cases have addressed the provision of auxiliary aids and services as a form of reasonable accommodation for individuals with psychiatric disabilities. Because the ADA specifically lists provision of such assistance as a possible reasonable accommodation, ${ }^{250}$ courts interpreting the ADA will need to take special care in examining claims of psychiatrically disabled individuals where such assistance was or should have been considered as an accommodation of the claimant's psychiatric disability. A clearly misguided approach, taken under the Rehabilitation Act, is demonstrated in Baxter v. Wisconsin Dept. of Natural Resources. ${ }^{251}$ In Baxter, the plaintiff, who suffered from severe depression, requested a job coach as an accommodation under the Rehabilitation Act, to help improve her productivity and her ability to follow directions. Though her vocational counselor offered to provide a job coach at no cost to the employer, the employer declined the offer. Plaintiff continued to experience productivity problems at work and was ultimately terminated. ${ }^{252}$

248. Id. (emphasis added).

249. See supra Part II.B.2.

250. See 42 U.S.C. § 12102 (1996); 29 C.F.R. § 1630.2(0)(2)(ii) (1996).

251. 3 Nat'l Disability L. Rep. (LRP) II 195 (Wisc. Ct. App. 1991).

252. See id. at 3 . 
In its opinion, the court acknowledged that the Rehabilitation Act contemplated such reasonable accommodations as readers and interpreters, but failed to see the connection between these sorts of accommodations for physically disabled individuals and the job coach plaintiff requested for her psychiatric disability. "Readers are provided to the blind and interpreters to non-English speaking employees on account of handicap. The nexus between those accommodations and those handicaps is easy to see.... But no nexus is shown between Baxter's mental depression and a job coach."253 Baxter demonstrates that courts and employers may not "get" mental illness because they cannot see the problem or possible solutions. Under the ADA, courts will be confronted with requests for accommodations that may not be immediately understandable to them. The analysis that courts are called upon to perform, however, has little to do with whether the court finds the accommodations efficacious and everything to do with a determination of whether the employer and employee engaged in the kind of interactive process that the $\mathrm{ADA}$ requires to reach an acceptable reasonable accommodation. ${ }^{254}$ Courts should not be engaging in determinations of whether the proposed accommodation is one that would or would not work. Sua sponte determinations that a proposed accommodation has no connection to the disability are inappropriate. Where the issue is whether an accommodation is one that will enable the employee to "be considered for the position [or] ... to perform the essential functions of that position," 255 courts must turn to evidence presented by the parties rather than their own "common sense."

In sharp contrast to Baxter is one of the leading cases interpreting reasonable accommodation of physical disability, Nelson $v$. Thornburgh. ${ }^{256}$ The court in Nelson found that Pennsylvania's Department of Welfare was required to hire readers for three blind workers, and that the cost of doing so did not constitute an undue hardship. ${ }^{257}$ The court focused on whether the accommodation was reasonable in light of the burden on the employer. On this issue, the court found that even a substantial cost did not amount to an undue burden on the employer. The Nelson court did not require plaintiffs to make clear the connection between their suggested accommodation and its usefulness, nor to prove that the accommodation would in fact enable them to fulfill all the essential functions of the position. Courts interpreting the ADA should take the approach of Nelson and conduct an analysis that

253. II. at 4-5.

254. See 29 C.F.R. \& 1630.2(0)(3) (1996).

255. Id. § $1630.2(0)(1)$.

256. S67 F. Supp. 369 (E.D. Pa. 1983), aff $d$ without op., 732 F.2d 146 (3d Cir. 1984).

257. See id. at 380. 
does not show skepticism or bias when considering the efficacy of a proposed accommodation, but instead focuses on the requirements of the statute and regulations.

\section{Allocation of Burdens}

The Baxter case is also inappropriate precedent in that it shifts the burden of persuasion on the issue of reasonable accommodation from the employer to the employee. The ADA arguably by its very terms makes the duty to demonstrate accommodation the employer's responsibility by making failure to accommodate unlawful. ${ }^{258}$ Though the $\mathrm{ADA}$ does not state an allocation of burdens for the various elements of a case, Congress specified that the burdens should be allocated consistent with cases brought under the Rehabilitation Act. ${ }^{259}$ Rehabilitation Act cases, however, are inconsistent as to the allocation of burdens and did not spell out the unlawfulness of failure to accommodate as the ADA does, making Congress' mandate somewhat unclear.

One commentator has delineated several approaches to the question of the burden of persuasion for reasonable accommodation that courts have taken under the Rehabilitation Act, arguing that only one, that taken in Prewitt $v$. United States Postal Service, ${ }^{260}$ makes sense under the ADA. ${ }^{261}$ The approach taken in Baxter, that the employee demonstrate conclusively that she would be qualified with the requested accommodation in place, allows the employer to skirt the duty of accommodation and avoid the kind of factual, interactive inquiry that the ADA requires. On the other hand, in Prewitt, the court found that under the Rehabilitation Act the employer has the duty to make a reasonable accommodation and thus the burden of proving its inability to make the accommodation. ${ }^{262}$ This allocation makes more sense, according to the court, because the employer has greater access to the information, resources, and advice of outside sources needed to determine what accommodations may work and what their costs will be. Once a plaintiff introduces credible evidence that an accommodation is possible, it is up to the employer to demonstrate that it made the necessary inquiry and to show that no reasonable accommodation was possible. ${ }^{263}$ Consequently, Baxter and other cases ${ }^{264}$ that put the burden on the plamtiff to

\footnotetext{
258. See 29 C.F.R. $\$ 1630.9$ (1996).

259. See H. R. Rep. No. $485-100$, pt. 2, at 72 (1990).

260. 662 F.2d 292 (5th Cir. 1981).

261. See Cooper, supra note 63, at 1463-66.

262. See Prewitt, 662 F.2d at 308.

263. See id. at 309-10; see also Arneson v. Heckler, 879 F.2d 393 (8th Cir. 1989) (holding that employee need only make a facial showing that reasonable accommodation is possible and burden then shifts to employer to prove inability to accommodate).

264. See, e.g., Carrozza v. Howard County, Md., 847 F. Supp. 365 (D. Md. 1994) (granting defendants summary judgment based on plaintiff's "conclusory" suggestions that defendants could
} 
prove that some accommodation would render her qualified and that it is a reasonable accommodation, are not good precedent for interpreting the ADA's more stringent requirement of reasonable accommodation.

\section{When is a Burden Undue?}

Another clear difference between the Rehabilitation Act and the $\mathrm{ADA}$ is the level of burden an employer must show to demonstrate that an accommodation is not reasonable. Under the Rehabilitation Act, cases addressing plaintiffs with physical disabilities ${ }^{265}$ and those with psychiatric disabilities $^{266}$ held that any hardship greater than a de minimus degree amounted to an undue burden. The legislative history $^{267}$ and regulations ${ }^{268}$ repudiate this de minimus standard in favor of one that requires employers to make significant accommodations.

Though employers may take into account the disruptive impact of a proposed accommodation on the workplace, negative impact on morale of other employees is not a legitimate part of this calculus. ${ }^{269}$ Decisions under the Rehabilitation Act have split on the issue of whether interpersonal problems resulting from attempts to accommodate an individual with a disability will constitute an undue burden. In a case involving the discharge of an employee with alcoholism and depression, the court granted the employee a preliminary injunction over her employer's protestations that accommodating the plaintiff's disability caused "serious morale problems" among her co-workers. ${ }^{270}$ In another case arising under the Rehabilitation Act, a court found that the negative sentiments of other employees toward a worker with mental retardation were not an undue burden on the employer and that the employer in fact had a duty to accommodate the worker by protecting her from the harassing comments of her co-workers. ${ }^{271}$

However, not all Rehabilitation Act cases have recognized the distinction between run-of-the-mill personality conflicts and interpersonal problems precipitated by an employee's mental illness. Often, the nature of an employee's illness is expressed through interpersonal limitations. Frequently, though, on-the-job conflicts will arise from nondisabled employees' preconceptions, fears, and prejudices against people with mental illnesses. The disposition of the case may hinge on

have reasonably accommodated the limitations of her bipolar disorder through any of four specific changes to her job), aff'd, 45 F.3d 425 (4th Cir. 1995).

265. See, e.g., American Fed'n of Gov't Employees v. Baker, 677 F. Supp 636, 638 (N.D. Cal. 1987).

266. See, e.g., Doe v. New York Univ., 666 F. 2d 761, 780 (2d Cir. 1981).

267. See S. Rep. No. 116-101, at 35 (1989); H. R. Rep. No. 485-101, pt. 3, at 67 (1990).

268. See 29 C.F.R. 1630 app. $\$ 1630.2$ (p) (1996).

269. See Disability Discrimination, supra note 18, at lll-13.

270. Callicotte v. Carlucci, 698 F. Supp. 944, 951 (D.D.C. 1988).

271. Kent v. Derwinski, 790 F. Supp. 1032 (E.D. Wash. 1991). 
whether the employee is blamed for the behavior or the behavior is seen as beyond his control and amenable to accommodation. For example, in Palmer v. Circuit Court, ${ }^{272}$ the court framed the interpersonal conflict in the workplace as "plaintiff"s ... inability to deal with her co-workers in a civil manner."2733 Rather than engage in an analysis that examined the degree to which the conflicts arose from other employees' negative reactions to a co-worker with a delusional disorder and depression, or that asked whether the disabled worker's symptoms might have been reasonably accommodated by her employer, the court simply found that the employer had no obligation to accommodate the worker ${ }^{274}$ Again, even if we agree that the court's ultimate decision was appropriate, the way in which it arrived at the decision was faulty. The EEOC and the Rehabilitation Act cases above have clearly repudiated the idea that such attitudes establish a defense to the duty of reasonable accommodation. Courts need to be aware that precedent to the contrary, such as Palmer, is not valid under the ADA.

\section{CONCLUSION}

Judges should carefully examine their nse of Rehabilitation Act precedent to be certain that those cases are not inappropriate for interpreting the $\mathrm{ADA}$, either by virtue of changes in the statute and its implementing regulations or because of the legislative intent of the statute. When determining the existence of a disability, courts should keep in mind that the ADA requires the court to determine disability without regard to mitigating measures such as medication. Determinations of disability should similarly be made without regard to the "voluntariness" or mutability of some symptoms of the disability. They should also be made with realistic assessments of the effect a disability will have on a person's daily fnnctioning and ability to work, rather than illogically literalist conclusions that only one job is affected. Moreover, I recommend that diagnosis with certain severe psychiatric disorders should create a presumption of disability, since making a competent diagnosis in itself requires that the mental health professional diagnosing the person find severe impairment in daily living.

On the issue of qualification, courts should be certain that their analysis simultaneously considers the person's qualifications with the possibility of accommodation, as the ADA requires. The Davis

272. 905 F. Supp. 499 (N.D. Ill. 1995)

273. Id. at 509.

274. See id. at 510. The court based its decision regarding reasonable accommodation on the employer's characterization of the plaintiff as a threat to safety. However, the analysis of that "threat" was lacking in much depth and appeared from the facts given to be pretextual. See supra notes $170-174$ and accompanying text. 
standard, and its legacy, are no longer appropriate for interpreting the $\mathrm{ADA}$. Courts must require evidence of the essential functions of a job beyond the employer's mere assertions, especially when the alleged essential functions are of an interpersonal nature. Courts should scrutinize employer evaluations, particularly where the employer claims the psychiatrically disabled employee has engaged in misconduct. The ADA requires, at least, that employees with psychiatric disabilities be held to the same standard as other employees. I suggest that the ADA requires more than mere equal treatment when employee behavior is a direct result of a disabling condition.

Psychiatric disabilities are essentially behaviorally-manifested disabilities; denying protection of employee behavior will too often mean denying ADA protection to people with psychiatric disabilities if employers are allowed to take adverse action without considering the possibility of accommodation. Where employers claim that a psychiatrically disabled employee presents a direct threat, courts must make a searching analysis that takes into account pervasive myths about the heightened dangerousness of the mentally ill and that guards against paternalism on the part of the employer. Courts should be especially wary of employer claims that employment would be a threat to the employee herself, given that there is little support in the statute or its legislative history for such a position.

On the issue of reasonable accommodation, courts will now be required to hold employers to a higher standard of accommodation, a standard that scrutinizes the kind of inquiry the employer has made, the possible effect of the accommodations offered, and the actual burden the accommodation would pose. Employers must prove that they attempted or considered accommodations and must show that those accommodations were not reasonable. It is up to the parties, not the court, to assess the efficacy of an accommodation. No longer should courts relieve employers of their duty to accommodate on the basis of only minimal burdens, whether they be economic or interpersonal.

Accomodations for individuals with psychiatric disabilities often fall into the latter category, requiring changes in attitudes and reactions. These are the exact sorts of changes that are the very heart of the ADA's promise to all people with disabilities. As difficult as physical barriers are to get past, the social barriers to full integration of people with disabilities are the most pervasive and pernicious. Accessibility and physical accommodation will not automatically bring full inclusion. As the Supreme Court itself has acknowledged, "society's accumulated myths and fears about disability and disease are as handicapping as are the [limitations] that flow from actual impairment."275 By examining

275. School Bd. of Nassau County v. Arline, 480 U.S. 273, 284 (1987) (person with tuberculosis 
the barriers faced by employees with psychiatric disabilities, and the kinds of judicial interpretations that are likely to allow such barriers to remain in place, we can begin to set the kinds of standards that will fulfill the promise of the ADA for all people with disabilities, physical and mental.

The ADA requires new flexibility, new tolerance, and new creativity to meet its promise of nondiscrimination to individuals with psychiatric disabilities. Courts will, by virtue of the ADA, be put in a position of Inaking that promise a reality in the disparate cases that come before thein. The task will not be easy, and the guidance from the statute and regulations is not always clear. Keeping the promise, however, will mean a world of difference for individuals who continue to experience segregation and are effectively shut out of the "opportunity to coinpete on an equal basis and to pursue those opportunities for which our free society is justifiably fanous."276

$* * * * * * * *$

Author's Note: As this Comment was moments away from going to press, the EEOC issued new guidelines which address inany of the concerns I raise in this Comment, including the need to accommodate psychiatric disorders and the problem of parity of treatment between physical and psychiatric disabilities. ${ }^{277}$ What remains to be seen is whether courts and employers will follow these improved guidelines.

is a "handicapped person" under Rehabilitation Act).

276. 42 U.S.C. \& 1210I(a)(9) (1996).

277. See, Sheryl Gay Stolberg, Gray Matter: Breaks for Mental Illness: Just What the Government Ordered, N.Y. TIMES, May 4, 1997, at Section 4, p.1. 
